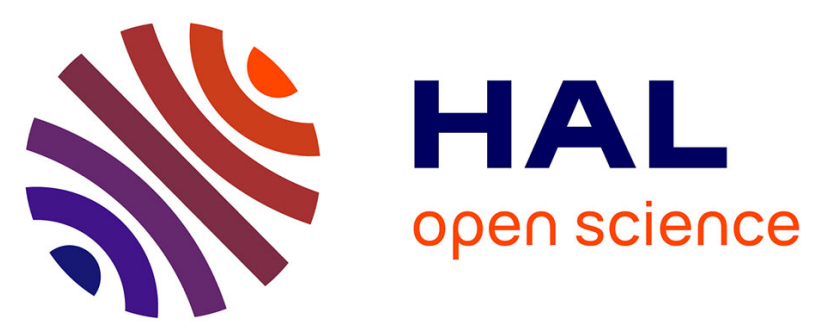

\title{
The ICTY's Power to Subpoena Individuals, to Issue Binding Orders to International Organizations and to Subpoena Their Agents
}

Anne-Laure Chaumette

\section{- To cite this version:}

Anne-Laure Chaumette. The ICTY's Power to Subpoena Individuals, to Issue Binding Orders to International Organizations and to Subpoena Their Agents. International Criminal Law Review, 2004, 4 (4), pp.357-429. 10.1163/1571812043020105 . hal-01661709

\section{HAL Id: hal-01661709 \\ https://hal.parisnanterre.fr/hal-01661709}

Submitted on 13 Dec 2017

HAL is a multi-disciplinary open access archive for the deposit and dissemination of scientific research documents, whether they are published or not. The documents may come from teaching and research institutions in France or abroad, or from public or private research centers.
L'archive ouverte pluridisciplinaire HAL, est destinée au dépôt et à la diffusion de documents scientifiques de niveau recherche, publiés ou non, émanant des établissements d'enseignement et de recherche français ou étrangers, des laboratoires publics ou privés. 


\title{
The ICTY's Power to Subpoena Individuals, to Issue Binding Orders to International Organisations and to Subpoena Their Agents
}

\author{
ANNE-LAURE CHAUMETTE
}

In international criminal law, the effectiveness of the prosecution of international crimes depends on access to evidence which is seemingly governed by consistent and efficient rules, especially those of evidence. However, international courts appear devoid of any substantive power of inquiry. Paradoxically, although the creation of the International Criminal Tribunal for the former Yugoslavia ${ }^{1}$ arose from the international community's consideration that elements proving that international crimes had been committed existed, the Tribunal has not been vested with an efficient enforcement power to compel the production of evidence.

This article focuses particular attention to two of the instruments contained in Rule 54 of the Rules of Procedure and Evidence ${ }^{2}$ of the ICTY: binding orders and the subpoena. ${ }^{3}$ Rule 54 enumerates the different instruments the Judges could wield to obtain relevant evidence. The term subpoena was added in January 1995, during the 5th plenary session of the ICTY, to "improve the clar-

\footnotetext{
${ }^{1}$ Hereinafter the "ICTY" or the "Tribunal".

2 Hereinafter the "RPE" or the "Rules".

3 The English version of Rule 54 of the RPE stipulates: "At the request of either party or proprio motu, a Judge or a Trial Chamber may issue such orders, summonses, subpoenas, warrants and transfer orders as may be necessary for the purposes of an investigation or for the preparation or conduct of the trial". The same word appears in the English version of the RPE of the ICTR. On the contrary, the concept of subpoena disappeared from the Statute of the International Criminal Court. Indeed, the International Law Commission had thought of inserting it in Article 26 of the Draft Statute which stated: "the Presidency may, at the request of the Prosecutor, issue such subpoenas and warrant as may be requested for the purposes of an investigation". Nevertheless, this provision is not included within the final version of the Statute adopted in 1998. The ICC is thus deprived of a controversial enforcement power, but useful to the Judges in compelling the production of evidence.
} 
ity, consistency and completeness of the rules". ${ }^{4}$ The expression 'sub poena' does not appear in the French version of Rule 54 of the RPE, ${ }^{5}$ but is instead reproduced through the phrase 'ordonnances de production ou de comparution forcées' ${ }^{6}$ The French term includes the adjective 'forcés'; it does not, however, endow the orders with the threatening scope of the subpoena. This terminological difference arises from the ignorance, in the civil law tradition, of the 'subpoena' which "carries with it the threat of sanction", 7 unlike in the common law tradition, where the subpoena is taken to constitute a judicial order which demands that its addressee either should appear before the Court subpoena ad testificandum ${ }^{8}$ - or bring relevant evidence - subpoena duces tecum $^{9}$-, under threat of penalty.

When the French and the English versions of the RPE differ, Rule 7 provides that the version to be preferred is that which most reflects the spirit of the Statute and the RPE. Within this framework, there are two conflicting theories: should the term 'subpoena' be understood in its traditional meaning as an order wherein penalties may be brought for non-compliance therewith? Or should a neutral meaning be adopted as 'binding order', which "does not necessarily imply the assertion of a power to imprison or fine". ${ }^{10}$ This debate crystallised

\footnotetext{
${ }^{4}$ Second Annual Report of the International Criminal Tribunal for the former Yugoslavia, August 23rd, 1995 [UN Doc. A/50/365-S/1995/728], para. 21.

5 The French version of Rule 54 of the RPE holds that "[à] la demande d'une des parties ou d'office un juge ou une Chambre de première instance peut délivrer les ordonnances, citations à comparaître, ordonnances de production ou de comparution forcées, mandats et ordres de transfert nécessaires aux fins de l'enquête, de la préparation ou de la conduite du procès" [emphasis added].

6 This phrase replaced the original term "assignation", at the alteration of the RPE, on July 27th, 1997 (i.e. eight days after the decision of the Trial Chamber in the Bla.kic case), in order to mirror the binding nature of this procedural order. This is worth noting that the Judges of the ICTR saw no point in changing Rule 54 of their Rules which is the counterpart of Rule 54 of the ICTY Rules. Therefore, the word "assignation" still figures in the French version of Rule 54 of the ICTR Rules.

${ }^{7}$ Carrillo Salcedo (J. A.), «The Inherent Powers of the International Criminal Tribunal for the Former Yugoslavia to issue 'subpoena duces tecum' to a sovereign State », Mélanges Valticos, 1999, at 271.

8 The subpoena ad testificandum may be defined as being "a writ directed to a person commanding him, under penalty, to appear and give evidence", Mozley and Whiteley's Law Dictionnary, 11th ed. by E.R. Hardy Ivany, Rutterworths, 1993.

9 The subpoena duces tecum may be defined as being "a writ directed to a person, requiring him not only to give evidence, but to bring with him such deeds or writings as the party who issues the subpoena may think material for his purpose", ibidem.

${ }^{10}$ ICTY Trial Chamber II, July 18th, 1997, Decision on the Objection of the Republic of Croatia to the Issuance of Subpoena Duces Tecum, Prosecutor/Tihomir Bla·kić, IT-95-14-PT, para. 62 .
} 
during the Bla·kic case when the ICTY Prosecutor Louise Arbour requested that the Tribunal issue a subpoena duces tecum to Croatia, its Defence Minister, Mr Susak, to Bosnia and Herzegovina, and to the Custodian of the Records of the Central Archive. ${ }^{11}$ Croatia challenged the power of the ICTY to do so; therefore, the Judges were obliged to declare whether the criminal nature of the subpoena might be reconciled with the Tribunal's inability to adjudge on the delicate question of State responsibility. The amici curiae in the Bla.kic case gave the notion of 'subpoena' various meanings. Some authors asserted that this concept should be interpreted within the peculiar context of international criminal law because the specific structure of the international society requires appropriate penalties. ${ }^{12}$ These amici curiae $^{13}$ consider that since both the civil law and the common law traditions jointly influenced the drafting Rules, the borrowed institutions and instruments therefrom could not be used in accordance with their ordinary meaning within these traditions; rather, they had to be adapted to the ICTY's sui generis legal order so as to reconcile both reference systems. Therefore, under this doctrine, the 'subpoena' sheds its criminal sanction and becomes an ordinary binding order. Other amici curiae ${ }^{14}$ put forward that the criminal sanction inherent to the common law subpoena should be retained, while ensuring its compatibility with international law. Thus, a distinction between the instruments according to their addressees has emerged:

${ }^{11}$ Prosecutor's Request for the Issuance of Subpoena Duces Tecum to Croatia, Prosecutor/ Tihomir Bla·kić, January 15th, 1997, IT-95-14-PT.

${ }^{12}$ Eustathiades (C. Th.), « Les sujets du droit international et la responsabilité internationale », Collected Course of The Hague Academy of International Law, 1953-III, vol. 84, at 438: “en s'attachant à des terminologies du droit interne qui prêtent à des malentendus lorsqu'on les applique sur le plan international, on risque de perdre de vue que la Communauté internationale présente une structure toute particulière qui impose des sanctions adaptées à cette structure".

${ }^{13}$ See, for example, the amicus brief by Bruno Simma who considers that "the question of enforcement measures available in case of unjustified non-compliance is not covered by the mere reference to subpoena in the English version of Rule 54", Prosecutor/Tihomir Bla·kić, September 8th, 1997, IT-95-14-PT, at 10. Also, the amicus brief by Professor Elder Bruce who points out that "the terms 'orders' and 'subpoena duces tecum' are interchangeable", Prosecutor/Tihomir Bla·kić, September 19th, 1997, IT-95-14-AR108bis, at 9.

${ }^{14}$ See, especially, the amicus brief by Professor Domestici-Met who suggests the alternative that one should "considérer la subpoena adressée aux Etats comme nulle et non avenue, le juge devant [...] prendre un nouvel acte sous forme d'ordonnance", Prosecutor/Tihomir Bla·kić, April 11th, 1997, IT-95-14-PT, at 6. See also the amicus brief by 'Juristes sans frontières' and Alain Pellet who considers that "les 'subpoenas' ont, par définition et nécessairement un caractère pénal; à ce titre, elles ne peuvent viser que des individus, à l'exclusion des Etats [. . .] car le Tribunal ne peut prononcer de sanctions pénales à leur encontre", Prosecutor/Tihomir Bla·kić, September 15th, 1997, IT-95-14-AR108bis, para. 3 and their amicus brief submitted to the Trial Chamber, Prosecutor/Tihomir Bla·kić, April 15th, 1997, IT-95-14-PT, para. 13-20. 
the subpoena keeps its criminal nature and can only be issued to individuals, whereas only binding orders may be issued to States. The ICTY Appeals Chamber settled this debate one and for all in the Bla.kic Judgement of October 29th, 1997. ${ }^{15}$ The Judges criticized the weakness of the decision of the Trial Chamber which had given the 'subpoena' an extensive and flexible meaning free of any criminal connotation. Instead, the Appeals Chamber accepted as its own the restrictive theory of the second group of authors: it considered it more relevant to issue binding orders to States, and subpoenas to individuals acting in their private capacity. The French phrase 'ordonnances de production ou de comparution forcées' can thus be translated by either 'binding orders' or 'subpoenas' depending on the identity of the addressee as a State or an individual. Therefore, the word 'subpoena' in the English version of Rule 54 of the RPE has a smaller scope than its French translation. On the other hand, the main aim of this provision is to compensate for the Tribunal lacuna, namely: the inability of the ICTY to respect the forum delicti commissi principle.

Although the creation of the ICTY stems from Security Council resolutions, ${ }^{16}$ the efficiency of its missions, as stated by the Special Rapporteur, ${ }^{17}$ must be balanced with a major challenge, namely, the Tribunal's relative distance from the scene of the crimes. The Tribunal's location, located in The Hague, is inconsistent with the forum delicti commissi principle, thus raising the corollary problems in the access to evidence and regarding the judicial means of investigation. Indeed, one notes that "the great majority of the witnesses and the greater part of the evidence are concentrated in that State [in

${ }^{15}$ ICTY Appeals Chamber, October 29th, 1997, Judgement on the Request of the Republic of Croatia for Review of the Decision of Trial Chamber II of 18 July 1997, Prosecutor/ Tihomir Bla·kić, IT-95-14-AR108bis.

${ }^{16}$ The United Nations Security Council followed the recommendation of the United Nations Special Rapporteur by establishing, under resolutions 808 (1993) and 827 (1993), the ad hoc "International Tribunal for the Prosecution of Persons Responsible for Serious Violations of International Humanitarian Law Committed in the Territory of the Former Yugoslavia since 1991". The international community of States, considering that international justice and international peace are inextricably linked, wanted to put en end to the threat of international peace and security the situation in the former Yugoslavia constituted.

${ }^{17}$ In 1992, the United Nations Special Rapporteur on the situation of human rights in the former Yugoslavia pointed out that "there is growing evidence that war crimes have been committed. Further investigation is needed to determine the extent of such acts and the identity of those responsible, with view to their prosecution by an international tribunal, if appropriate", Mazowiecki (T.), United Nations Special Rapporteur on the situation of human rights in the former Yugoslavia, Report of the Special Rapporteur, November 17th, 1992 [UN Doc. A/47/666-S/24809 (1992)], para. 140. 
which the offence was committed], and it becomes, therefore, the most convenient place (forum convenicus) for the conduct of the trial". ${ }^{18}$ Yet, as the ICTY is very concerned about obtaining evidence, it needs to be endowed with efficient procedural mechanisms. One might contemplate referring to previous cases of the Nuremberg and Tokyo International Military Tribunals as a valid precedent; the comparison fails, however. Those tribunals, unlike the ICTY, were consistent with the forum delicti commissi principle, and furthermore, "the procedural and evidentiary rules adopted by the post-WW II tribunals proved too rudimentary to be useful to a long term enterprise like the ad hoc tribunals". ${ }^{19}$ Therefore, the ICTY Judges were obliged to build a sui generis procedural regime, whose rules appear in the RPE. The legal basis of their creation may be found in Article 15 of the ICTY Statute ${ }^{20}$ which, though outlining the procedure, grants the Judges the authority to draft accurate rules within the framework of inviolable pre-established standards..$^{21}$ The RPE is thus the first set of Rules of international criminal procedure, and furthermore, also sets up the first international corpus of rules of evidence in criminal law. Within this probationary system, Rule 54 of the RPE is central: it is a residual provision ${ }^{22}$ the Tribunal uses to develop certain enforcement powers to compel the production of evidence not expressly provided for in the RPE, but limited to the jurisdiction granted by its Statute.

The interpretation of Rule 54 of the RPE has an impact vis-à-vis international law. In a comprehensive study of the ICTY, Professor Condorelli considered that there is a penalization of international law. ${ }^{23}$ The International

${ }^{18}$ Supreme Court of Israel, Judgement of May 29th, 1962, Eichmann, International Legal Reports, vol. 36, 1968, at 302.

${ }_{19}$ Bohlander (M.), «International Criminal Tribunals and their Power to Punish Contempt and False Testimony », Criminal Law Forum, vol. 12, 2001, $\mathrm{n}^{\circ}$ 1, at 91.

${ }^{20}$ Article 15 of the Statute, regarding the Tribunal's Rules, states: “The judges of the International Tribunal shall adopt rules of procedures and evidence for the conduct of the pretrial phase of the proceedings, trials and appeals, the admission of evidence, the protection of victims and witnesses and other appropriate matters".

${ }^{21}$ Champy (G.), «Inquisitoire - Accusatoire devant les juridictions pénales internationales », Revue internationale de droit pénal, vol. 68, 1997, at 150 (our translation of "le juge pénal international est ainsi susceptible de générer les règles qu'il s'appliquera à lui-même dans le cadre des normes intangibles prét́tablies").

${ }^{22}$ Ackerman (J.E.) and O'Sullivan (E.), Practice and Procedure of the International Criminal Tribunal for the Former Yugoslavia - with selected materials from the International Criminal Tribunal for the Rwanda, Kluwer Law International, The Hague, 2000, at 277.

${ }^{23}$ Condorelli (L.), «Le Tribunal pénal international pour l'ex-Yougoslavie », in Cours euroméditerranéens Bancaja de droit international, vol. I, 1997, Aranzadi, Pampelune, 1998, at 247: "l'étude du T.P.I.Y. oblige à [ . . . ] analyser et apprécier une œuvre de pionnier dans le sillage de ce qu'on indique comme la tendance à la 'criminalisation' du droit international”. 
Tribunals $^{24}$ and the new International Criminal Court ${ }^{25}$ contribute to the development of a new branch of international law: international criminal law. This evolution has enriched the international legal order. Nevertheless, this penalization is far from absolute, as it is limited by the very sources of international law and the basic principles contained therein. Indeed, criminal law has had to adjust itself and to respect the grounds of the jus gentium governing international relations. In international law, there exists an imbalance between the legal standing of States and of individuals. Within this system where the sovereignty of States remains a paramount consideration, the criminal rules may only play a small part vis-à-vis States; on the contrary, the individual, who does not enjoy such sovereignty, is not protected from threatening or coercive measures. The mechanism of the subpoena before the ICTY is consistent with and reinforces this disparity: States remain the genuine subjects of international law, whereas individuals only have a limited legal capacity. ${ }^{26}$ In other words, individuals hold a minor position within the probationary system of the ICTY, which remains deeply rooted in the inter-State paradigm. Although this conception is challenged by some modern authors, who argue that individuals are entitled to plenary standing in international law, ${ }^{27}$ like its primary subjects; however, this recent argument, which disregards the inter-State nature of international law, denies the concrete reality of jus gentium. Consequently, the traditional theory, which considers the State as the original subject with a plenary legal capacity and the individuals as subordinate subjects, is still topical although one should qualify it.

This article aims to illustrate this thesis through two studies, i.e. the ICTY's power to subpoena individuals (Individuals) and the ICTY's power to issue binding orders to international organisations and to subpoena their agents (Organisations and their agents).

\footnotetext{
${ }^{24}$ The International Criminal Tribunal for Rwanda was created by SC resolution 955 (1994) of November 8th, 1994; the Special Court in Sierra Leone whose creation was suggested by the Security Council in its resolution 1315 (2000) of August 14th, 2000 has been established by the Agreement between the United Nations and the Government of Sierra Leone of January 16th, 2002.

25 The ICC Statute entered into force on July 1st, 2002.

${ }^{26}$ Daillier (P.) and Pellet (A.), Droit international public, L.G.D.J., Paris, $7^{\mathrm{e}}$ edition, 2002, para. 418 , at 649.

27 According to Professor F. A. Acakpo Satchivi, "l'individu est devenu un sujet direct du droit international au même titre que l'Etat”, Les sujets de droit - contribution à l'étude de la reconnaissance de l'individu comme sujet direct du droit international, L'Harmattan, Paris, 1999, at 570. Likewise, G. Scelle considers that the individual is an active subject of international law since any legal order is built for mankind 'hominum causa omne jus constitutum est'.
} 


\section{Individuals}

Within international criminal procedure, States are not subjected to the ICTY's authority, even if they have a duty to cooperate therewith. Indeed, under paragraph 4 of Resolution $827(1993)^{28}$ and Article 29 of the Statute, ${ }^{29}$ States must adopt laws of implementation and comply with the Judges' orders. Nevertheless, whereas the ICTY needs States' cooperation, ${ }^{30}$ it is "vested with any enforcement or sanctionary power vis-à-vis States" 31 so that it cannot issue a subpoena to them. The Judges may only issue binding orders, which entitle them to demand the compliance of orders for the production of evidence, but not to impose penalties upon States. ${ }^{32}$ Thus, the mechanism of the binding order according to the Bla kić case allows the Trial Chamber to make a judicial finding ${ }^{33}$ and to report non-observance therewith to the Security

28 This paragraph stipulates that "all States shall cooperate fully with the International Tribunal and its organs in accordance with the present resolution and the Statute of the International Tribunal and that consequently all States shall take any measures necessary under their domestic law to implement the provisions of the present resolution and the Statute, including the obligation of States to comply with requests for assistance or orders issued by a Trial Chamber under Article 29 of the Statute".

${ }_{29}$ According to this provision: "1. States shall co-operate with the International Tribunal in the investigation and prosecution of persons accused of committing serious violations of international humanitarian law. 2 . States shall comply without undue delay with any request for assistance or an order issued by a Trial Chamber, including, but not limited to: (a) the identification and location of persons; (b) the taking of testimony and the production of evidence; (c) the service of documents; (d) the arrest or detention of persons; (e) the surrender or the transfer of the accused to the International Tribunal". This duty to cooperate also appears in the Statute of others international criminal courts, such as Article 28 of the ICTR Statute and Article 86 of the Statute of ICC. The constant reiteration of this obligation reveals its relevance in international criminal proceedings. Indeed, the efficiency of international criminal tribunals relies upon the State duty to assist them, especially for the production of evidence.

${ }^{30}$ Antonio Cassese underlined that "the Tribunal has no enforcement agencies at its disposal: [. . . ] without the intermediary of national authorities, it cannot seize evidentiary material [. . .]. It must turn to State authorities and request them to take action. Our Tribunal is like a giant who has no arms and no legs. To walk and work, he needs artificial limbs. The artificial limbs are the State authorities; without their help the Tribunal cannot operate", Statement of the President of the ICTY before the General Assembly of the United Nations, November 7th, 1995.

${ }^{31}$ Bank (R.), "Cooperation with the International Criminal Tribunal for the Former Yugoslavia in the Production of Evidence », Max Planck Yearbook of United Nations Law, 2000, at 247.

32 The power of the ICC to compel States to cooperate for the production of evidence is much more limited, because, pursuant to Article 93 of its Statute, the Judges may only issue "measures of assistance" to States.

${ }^{33}$ Pursuant to Rule 7bis of the RPE, the Judges of the ICTY "may advise the President, who shall report the matter to the Security Council". According to L. Condorelli, a judicial finding 
Council, which may impose sanctions against the recalcitrant State. The system established by the Bla.kic case relies upon voluntary cooperation of States, which retain control in binding order proceedings.

On the other hand, individuals remain in a subordinate relation vis-à-vis both the International Tribunal and States. However, they are not just the objects of the proceedings. Within international criminal proceedings, individuals are subordinate subjects and enjoy merely passive legal personality. Even though They may be subpoenaed by the ICTY (Part I), their legal capacity remains comparatively small because they nevertheless require State supervision (Part II).

\section{Part I. The ICTY's authority over individuals}

In international law, the witness' evidence is of secondary value. As a consequence of the rare resorting to witnesses, the courts which have jurisdiction over inter-State disputes "are not principally allowed to call witnesses of their own. Nor do they normally have the power to compel the presence of a witness at the request of parties." ${ }^{34}$ Nevertheless, international criminal proceedings are inspired by the common law tradition, wherein evidence "is generally required in the form of oral testimony from witnesses." 35 The testimony of those who directly witnessed the crimes is essential for prosecuting the accused, thus, the Judges of the ICTY need efficient legal implements to ensure the appearance of the witness or the production of the documents in his or her possession. Therefore, the Judges consider that, pursuant to Rule 54, they may subpoena a wide category of persons to appear before the Tribunal (Section I). These criminal orders allow the Judges to hold individuals who did not comply with their subpoenas in contempt of the Tribunal (Section II).

\section{Section I. The addressees of the subpoenas}

The efficiency of the ICTY in the fulfilling of its mandate hinges upon the quality of the evidence which has to be disclosed to the Tribunal. The ICTY's power to issue subpoenas ad testificandum and subpoenas duces tecum was at first

is a "sorte de dénonciation publique et solennelle de l'Etat fautif au Conseil de sécurité. Autrement dit, le Tribunal dénonce aux Nations Unies un fait internationalement illicite d'un Etat qui a été judiciairement établi", supra [note 23], at 253-254.

${ }^{34}$ Kazazi (M.), Burden of Proof and Related Issues - A Study on Evidence before International Tribunals, The Hague, Kluwer, 1996, at 170.

${ }^{35}$ Findlay (M.), «Synthesis in Trial Procedures? The experience of International criminal tribunals », International Comparative Law Quarterly, vol. 50, 2001, n 1 , at 40. 
limited to individuals not acting in their official capacity (I); then it was broadened to 'individuals acting in their private capacity' (II). The ICTY Judges are therefore vested with the enforcement power to compel many witnesses to provide the Tribunal with the information they possess.

\section{The initial distinction between 'individuals acting in their private capacity' and State officials}

A priori, the ICTY's power seemed restricted: according to the doctrines of Act of State and the principle granting functional immunity to State agents, the Appeals Chamber, in the Bla. kic case, declined the issue of a subpoena to State officials (B). Indeed, the ICTY could only subpoena individuals to appear (A).

\section{A. The ICTY power to subpoena individuals}

The ICTY has jurisdiction over not only any individual suspected of having committed an international crime, but also over individuals qua witnesses (1). Under this auxiliary jurisdiction, the Judges may issue subpoenas to private persons (2).

\section{ICTY jurisdiction over individuals}

Articles 1 and 6 of its Statute vest the ICTY with "jurisdiction over natural persons" "responsible for serious violations of international humanitarian law committed in the territory of the former Yugoslavia since 1991". This power derives from the Nuremberg principle according to which: "It was submitted that international law is concerned with the action of sovereign States, and provides no punishment for individuals. [. . .]. In the opinion of the Tribunal, [this submission] must be rejected. [. . .] Individuals can be punished for violations of international law. Crimes against international law are committed by men, not by abstract entities, and only by punishing individuals who commit such crimes can the provisions of international law be enforced." ${ }^{36}$ Thus, the ICTY has the power to accuse, try, and adjudge individuals, subjects of international criminal law whose international responsibility is entailed. Nevertheless, this jurisdiction is expressly related to suspects of international crimes, and subpoenas remain aimed at individuals qua holders of documents or witnesses of crimes but not qua accused. Therefore, does the ICTY have jurisdiction over them?

\footnotetext{
${ }^{36}$ Nuremberg Trial, Judgement of the International Military Tribunal for the Trial of German Major War Criminals, official documents, t. 1, "The Law of the Charter”, at 234-235.
} 
First, as the ICTY must provide both with a fair hearing and an efficient repression of the crimes, the Judges need much evidence to be convinced. Consequently, they should be vested with jurisdiction over the witnesses. In addition, some provisions of the Statute are aimed at individuals who are not the accused. Article 19 (2) of the Statute allows the Judges of the Trial Chamber to issue orders "as may be required for the conduct of the trial". Likewise, Article 18 (2) of the Statute enables the Prosecutor to "question suspects, victims and witnesses, to collect evidence and to conduct on-site investigation". Consequently, the ICTY may address private persons, especially witnesses.

These remarks regarding both the Tribunal's mission and its Statute allow it to assume "an incidental and ancillary jurisdiction over individuals other than those whom the International Tribunal may prosecute and try". ${ }^{37}$ This complementary jurisdiction over witnesses supplements the ICTY's primary jurisdiction, over suspects. However, does such jurisdiction allow international criminal Judges to issue subpoena duces tecum and subpoena ad testificandum to individuals?

\section{The ICTY power to issue subpoenas to individuals}

Article 19 (2) of the Statute provides that the Trial Chamber can issue orders to individuals "as may be required for the conduct of the trial". This provision should be read in conjunction with Rule 54 of the RPE, which establishes that "the Trial Chamber may issue [...] subpoenas [. . .] as may be necessary for the purposes of an investigation or for the preparation or conduct of the trial". This twofold authority - Article 19 which grants the Tribunal jurisdiction over individuals, and Rule 54 which enables it to issue subpoenas - leads to the fact that the individual, "being within the ancillary (or incidental) criminal jurisdiction of the International Tribunal, is duty-bound to comply its orders, requests and summonses". ${ }^{38}$ As a result, the onus is upon the individuals in question to comply with orders of the ICTY made in accordance with the Statute. ${ }^{39}$ Professor Nouvel stresses that international courts hardly possess

\footnotetext{
${ }^{37}$ ICTY Appeals Chamber, October 29th, 1997, Judgement on the Request of the Republic of Croatia for Review of the Decision of Trial Chamber II of 18 July 1997, Prosecutor/ Tihomir Bla·kić, IT-95-14-AR108bis, para. 48.

${ }^{38}$ Ibid., para. 56. See also a previous decision which already asserted that "en vertu de l'article 54 du R.P.P. du Tribunal international, la Chambre de première instance est habilitée à décerner une injonction aux fins de témoigner à des individus concernant des informations qu'ils ont obtenues à titre privé", ICTY Trial Chamber II, October 16th, 1997, Ordonnance relative à la requête du Procureur concernant la délivrance d'injonctions aux fins de témoigner et d'une ordonnance décernée au Gouvernement de Bosnie-herzégovine, Procureur/Zejnil Delalić, Zdrako Mucić a/k/a 'Pavo', Hazim Delić, Esad Landžo a/k/a 'Zenga', IT-96-21-T.

${ }^{39}$ That an international instrument imposes duties on individuals is in accordance with the
} 
such a power since it allows the ICTY to compel subjects of domestic law to comply with injunctions of the international legal order. ${ }^{40}$ It may be noted here, however, on this very point, that through an obitur dictum, the Appeals Chamber in 1997 stated that the ICTY is vested with the power to issue subpoenas to individuals.

Furthermore, in order to avoid overzealous "fishing expeditions" and the misuse of this enforcement power, there are further requirements to issue a subpoena: the applicant must "identify expressly and precisely the legitimate forensic purpose for which the access is sought". ${ }^{41}$ In addition, he should "demonstrate a reasonable basis for his belief that there is a good chance that the prospective witness will be able to give information which will materially assist him in his case, in relation to clearly identified issues relevant to the forthcoming trial". ${ }^{42}$ In consequence, the ICTY articulated four standards to issue a subpoena: first, the criterion of preciseness; second, the criterion of relevance ${ }^{43}$ third, the criterion of inability by the applicant to obtain the witness' cooperation; and four, the criterion of usefulness. ${ }^{44}$

\section{B. ICTY inability to subpoena a State official}

Although it would be convenient to issue subpoenas to State officials who, after a regional conflict, possess documents that might be useful to curb international crimes, the Appeals Chamber, in the Bla.kić case, denied this power on the

principle that "it cannot be disputed that the very object of an international agreement, according to the intention of the contracting Parties, may be the adoption by the Parties of some definite rules creating individuals rights and obligations", PCIJ, Advisory Opinion of March 3rd, 1928, Jurisdiction of the Courts of Danzig, Series B, $\mathrm{n}^{\circ} 15$, at 17-18.

${ }^{40}$ Nouvel (Y.), «Précisions sur la compétence du Tribunal pénal international pour l'exYougoslavie d'ordonner la production de preuves et la comparution des témoins : l'arrêt de la Chambre d'appel du 29 octobre 1997 dans l'affaire Bla·kić », Revue générale de droit international public, 1998, note 14, at 161. The Judges of the ICC seem to be vested with the same power pursuant to Article 64 (6) of the Statute since they may "require the attendance and testimony of witnesses and production of documents and other evidence". However, this provision does not expressly endow this measure with a threatening meaning.

${ }^{41}$ Separate Opinion of Judge David Hunt on Motion by Esad Landzo to Preserve and Provide Evidence, April 22nd, 1999, Prosecutor/ Zejnil Delalić, Sdravko Mucic a/k/a 'Pavo', Hazim Delic, Esad Landzo a/k/a 'Zenga', IT-96-21-A, para. 4.

${ }^{42}$ ICTY Appeals Chamber, July 1st, 2003, Decision on Application for Subpoenas, Prosecutor/Radislav Krstić, IT-98-33-A, para 10.

${ }^{43}$ There should be a 'good chance' that the information to be given will materially assist the appellant in relation to the case.

${ }^{44}$ The subpoena would make such collaboration possible. 
ground that State officials are protected by a jurisdictional immunity. ${ }^{45}$ Such an approach would seem at variance with the very existence of the Tribunal, whose jurisdiction is based upon the non-exemption of the State officials from individual criminal responsibility; ${ }^{46}$ nevertheless, the Judges' decision is not questionable since the ICTY denies it has the power to issue subpoenas to States.

Traditionally, before the courts of a State B, the officials of a State A enjoy an immunity which shields them from the jurisdiction of State B. This immunity is governed by both Vienna Conventions of 1961 and 1963, on diplomatic and consular relations, respectively. There are two forms of immunities: the immunity ratione personae (personal) which covers the private acts of the State agent throughout its mission; and the immunity ratione materiae (functional), which is an extension of the State jurisdictional immunity and protects the agent for its official acts even after the end of the mission. These immunities which exist within inter-State relations, are not opposable before the ICTY. Indeed, its Statute limits this privilege, as it vests the Tribunal with the power to prosecute State officials who are alleged to have committed an international crime. Article 7 (2) provides expressly that "[t]he official position of any accused person [. . . ] shall not relieve such person of criminal responsibility nor mitigate punishment". ${ }^{47}$ This rule, of the transparency of the State veil, constitutes one of the basic principles of international criminal law. As Prof. Jahrreiss stated: "the Indictment mentally wipes out the [. . . State for the time when it stood upright in its full strength and acted through its organs. It must do so if it desires to prosecute individual persons for a breach of the peace between States. It must turn the defendants into private individuals". ${ }^{48}$ Therefore, when a State official is tried by the ICTY for the crimes committed in the course of exercising his official functions, it is his own personal criminal responsibility which is entailed and not the responsibility of the State.

${ }^{45}$ ICTY Appeals Chamber, October 29th, 1997, Judgement on the Request of the Republic of Croatia for Review of the Decision of Trial Chamber II of 18 July 1997, Prosecutor/ Tihomir Bla· kić, IT-95-14-AR108bis, para. 18.

${ }^{46}$ See the Yerodia case before the ICJ, where the Judges stated that "Accordingly, the immunities enjoyed under international law by an incumbent or former Minister for Foreign Affairs do not represent a bar to criminal prosecution in certain circumstances. [. . . ] an incumbent or former Minister for Foreign Affairs may be subject to criminal proceedings before certain international criminal courts, where they have jurisdiction. Examples include the International Criminal Tribunal for the Former Yugoslavia", Case Concerning the Arrest Warrant of 11 April 2002 (Democratic Republic of Congo v. Belgium), Judgement of February 14th, 2002, para. 61.

${ }^{47}$ Articles 6 of the ICTR Statute and 27 of the ICC Statute also deny that the official position of the suspect allow for an exemption from his criminal responsibility.

${ }^{48}$ Dr Jahrreiss, Concluding speech by Defence on the legal issue of breach of peace, Nuremberg Military Tribunal, July 4th, 1946, Part. 3 of 8, at 92. 
In the Bla.kić case, the Trial Chamber used this line of argument to recognise the power to issue a subpoena to State officials. In its decision of July 18th, 1997, it considers that an order addressed to an individual acting in his official capacity does not concern his State. ${ }^{49}$ Such a conclusion did not seem immediately apparent as the Judges had previously stated that, "as States can act only through their officials, a high government official who is subpoenaed in his official capacity to carry out obligations on behalf of a State would not be taking past in the proceedings as a private person but as an agent of the State". ${ }^{50}$ Despite this apparent contradiction, the Judges of the Trial Chamber have accepted the possibility of issuing a subpoena to a State official, in the instant case, Mr Susak, the Defence Minister of Croatia.

This equivocal decision of the Trial Chamber was quashed by the Appeals Chamber on the October 29th, 1997. The Judges distinguished the State official accused of an international crime - who is not relieved from responsibility from the State official who is a witness of a crime - who enjoys immunity. The Appeals Chamber considered, basing its decision on the doctrine of the Act of State,,$^{51}$ that the State officials enjoy rationae materiae immunity. According to this judgement, "[s]uch officials are mere instruments of a State and their official action can only be attributed to the State" 52 so that they cannot be punished for an action undertaken on behalf of the State. The Appeals Chamber inferred that the ICTY did not have the power to subpoena State officials. The doctrine of the Act of State which extends personal immunity to the State act was viewed by Kelsen as "the generally recognised principle that the courts of a State are not competent with regard to another State. Consequently, this principle applies not only where the defendant is expressly designated as 'State $\mathrm{X}$ ' or the 'person' of State X, but also where the defendant is an individual sued personally or an act performed by him as an act of State X. The collective responsibility of a State for its own acts excludes, according to general international law, the individual responsibility of the person who, as a member of the government, at the command or with the authorisation of the government, has performed the act" ${ }^{53}$ According to this doctrine, any act of a State official

${ }^{49}$ ICTY Trial Chamber II, July 18th, 1997, Decision on the Objection of the Republic of Croatia to the Issuance of Subpoena Duces Tecum, Prosecutor/Tihomir Bla·kić, IT-95-14-PT, para. 92.

${ }^{50}$ Ibid., para. 89.

${ }^{51}$ ICTY Appeals Chamber, October 29th, 1997, Judgement on the Request of the Republic of Croatia for Review of the Decision of Trial Chamber II of 18 July 1997, Prosecutor/ Tihomir Bla·kić, IT-95-14-AR108bis, para. 39.

52 Ibid., para. 38.

${ }^{53}$ Kelsen (H.), Peace through Law, University of North Carolina Press, Chapel Hill, 1944, at 83 . 
is an act of his State, so that only State responsibility may be incurred. Apart from a permission of the official's national State, a foreign State is not entitled to try the agent at the risk of infringing the international principle of non-intervention in the internal affairs of any other State. ${ }^{54}$ This doctrine, which relieves State officials of any responsibility for acts performed within their official capacity, had been questioned in the Eichmann case. The Supreme Court of Israel considered that "the concept of 'sovereignty', from which the doctrine of 'Act of State' derives, is not considered today to be an absolute concept". ${ }^{55}$ Nevertheless, the doctrine of Act of State exists in international law: the International Law Commission's Draft Articles on State Responsibility for Internationally Wrongful Acts provide that an act carried out by State organs should be regarded as carried out by the State itself. ${ }^{56}$ Besides, the ICTY Appeal Chamber pointed out that "any internationally wrongful act of a State official entails the international responsibility of the State as such and not that of the official". ${ }^{57}$ In addition, one must note that international law allows the State to appoint the person in charge of an official mission. Therefore, State agents possess evidence only because they exercise a function upon consent of that State. Professor Bank would retort that "to allow States to choose whom they may wish to appoint for testifying on document related issues may have

\footnotetext{
${ }^{54}$ This is the application of a principle of international law, namely, the prohibition to intervene within the internal affairs of a State appears in Article 2 (7) of the UN Charter and in the resolution 2625 (XXV) of October 24th, 1970. This principle has been accepted by the ICJ, which has asserted that "the Court can only regard the alleged right of intervention as the manifestation of a policy of force, such as has, in the past, given rise to most serious abuses and such as cannot, whatever be the present defects in international organisation, find a place in international law", Judgement of April 9th, 1949, The Corfu Channel Case (United Kingdom/Albania), Rep. 1949, at 35. In 1986, the ICJ specified that "the principle forbids all States or groups of States to intervene directly or indirectly in internal or external affairs of other States", Judgement of June 27th, 1986, Case Concerning Military and Paramilitary Activities in and against Nicaragua (Nicaragua/United States of America), Rep. 1986, at 108.

${ }_{55}$ Supreme Court of Israel, Eichmann, supra [note 18], at 309.

${ }^{56}$ Article 4 of the International Law Commission's Draft Articles on State Responsibility for Internationally Wrongful Acts states that " 1 . the conduct of any State organ shall be considered as act of that State under international law [. . . . 2. an organ includes any person or entity which has that status in accordance with the internal law of that State".

${ }^{57}$ ICTY Appeals Chamber, October 29th, 1997, Judgement on the Request of the Republic of Croatia for Review of the Decision of Trial Chamber II of 18 July 1997, Prosecutor/ Tihomir Bla·kić, IT-95-14-AR108bis, para. 39. See also, Maison (R.), La responsabilité individuelle pour crime d'Etat en droit international public - De la sanction pénale des individus par les juri- dictions internationales, Thesis, Paris II-Assas, at 270: "si l'acte est réputé perpétré par l'Etat, et non par l'individu organe, ou l'individu le représentant, les conséquences de cette illicite étatique seront naturellement imputées, non à cet individu mais à l'Etat dont il est l'organe".
} 
negative practical repercussions on the quality of evidence" 58 . Indeed, issuing a subpoena to a State agent acting in his official capacity amounts to issuing a subpoena to his State, despite the ICTY being merely vested with the power to issue binding orders to the States. This incapacity also extends to State officials who possess evidence, because of their official action: "[i]l ne s'agit pas d'un obstacle normatif immunitaire. Il s'agit tout simplement [. . .] de la rencontre de la "limite verticale" du droit international, droit qui ne peut que très exceptionnellement dépasser les relations inter-individuelles exclusives qu'entretient l'Etat avec ses agents". ${ }^{59}$ Furthermore, if Article 18 (2) of the Statute enables the Prosecutor to "seek assistance of the State authorities" ${ }^{60}$ this provision, whose wording is not binding, does not create an obligation for State officials to cooperate. The duty to assist the ICTY to collect evidence only applies States. If the Prosecutor applies to such a State agent, it is because the State, in accordance with its obligation, has nominated the relevant organ to help the Tribunal and to disclose the documents. ${ }^{61}$ Therefore, when the ICTY applies to an State official, it apprehends him as a organ of State, not as an individual.

This reasoning was questioned in 2003. In the Krstić case, the Judges of the Appeals Chamber set out an eccentric interpretation of the Bla kić Judgement since, according to them, this decision was only concerned with the production of documents and "did not say that the functional immunity enjoyed by State officials includes an immunity against being compelled to give evidence of what the official saw or heard in the course of exercising his official functions". " ${ }^{62}$ Moreover, they considered that in the case of a subpoena ad testificandum, "unlike the production of State documents, the State cannot itself provide the evidence which only such a witness could give". ${ }^{33}$ Therefore, they con-

${ }^{58}$ Bank (R.), supra [note 31], at 246.

${ }^{59}$ Arangio Ruiz (G.), «Le domaine réservé - l'organisation internationale et le rapport entre droit international et droit interne », Collected Course of The Hague Academy of International Law, vol. 225, 1990-VI, at 9-484.

${ }^{60}$ ICTY Appeals Chamber, October 29th, 1997, Judgement on the Request of the Republic of Croatia for Review of the Decision of Trial Chamber II of 18 July 1997, Prosecutor/ Tihomir Bla·kić, IT-95-14-AR108bis, para. 42.

${ }^{61}$ Most of the national implementing legislation identifies the relevant organ: for instance, Articles 7 of the French Law, 3 of the Danish Act and 2 of the Italian Decree-Law appoint the Minister of Justice qua the central authority in charge of external relations with the Tribunal; under Article 4 of the Swiss Federal order, the Federal Office of Police receives the requests of the Tribunal and passes them on to the relevant authorities for their compliance; and Article 6 of the Austrian Federal Law leaves the Ministry of Foreign Affairs to communicate with the ICTY.

${ }^{62}$ ICTY Appeals Chamber, July 1st, 2003, Decision on Application for Subpoenas, Prosecutor/Radislav Krstić, IT-98-33-A, para. 27

${ }^{63}$ Ibid., para. 24. 
cluded that the ICTY is vested with the power to issue a subpoena ad testificandum to State officials. ${ }^{64}$ One should hope that this was a misinterpretation and that this departure will not be repeated. On the one hand, the decision of July 1 st, 2003 tends towards the automatic loss of immunity for State officials' (as accused and as witnesses). However, if States indicated their intention to waive the agents' functional immunities when accused of an international crime ${ }^{65}$ there are neither articles nor rules that demonstrate that same intention concerning the State official qua witness. On the second hand, the 2003 decision introduces an iniquity between the State official who holds the documents (who cannot be subpoenaed) and the State official who knows the content of these documents (who can be addressed a subpoena ad testificandum). Judge Shahabuddeen, appending a dissenting opinion, reminded that when the Judges adopted Rule 54 bis, they "understood the reasoning of the [Bla.kić] case to mean that both documents and information (where these were acquired by a State official in his official capacity) could only be obtained from the State [. . .] through a procedure for a binding order" ${ }^{66}$ Therefore, one should admit, despite the Krstić decision, that the Bla kić Judgement extends to any information gathered by the agent in his official capacity; and, if the Judges need evidence acquired by a State official, they must issue a binding order to his State.

Eventually, if there is no more room for doubt concerning the jurisdiction of the ICTY over individuals and its power to subpoena them, the power to issue subpoenas to State officials remains debatable. Furthermore, the criterion of distinction - individual/State official - has been qualified by the Appeals Chamber in its same decision on the October, 29th 1997 to allow the Judges to subpoena certain State agents in spite of their immunity.

\section{Broad interpretation of the concept of 'individuals acting in their private capacity'}

The power of the ICTY to issue subpoenas to individuals relies upon the nature of the witness' activity. If the State agent acting in his official capacity should enjoy immunity, on the contrary, the ICTY has jurisdiction over the

\footnotetext{
${ }^{64}$ Nevertheless, the Judges recognise that the State agent could decline to answer the questions on the grounds of confidentiality, and proceedings may be adapted if the testimony raises issues of national security.

${ }_{65}$ Article 7 (2) of the ICTY Statute.

${ }^{66}$ Dissenting Opinion of Judge Shahabuddeen, July 1st, 2003, Decision on Application for Subpoenas, Prosecutor/Radislav Krstić, IT-98-33-A, para. 5.
} 
State agent acting in his private capacity and it can subpoena him. In the Bla.kić Case, the Appeals Chamber identified four main situations wherein a State official acts in his private capacity; three of these situations are related to State organs and constitute waivers of the above principle. The last hypothesis concerns the peacekeepers and the agents of an international organisation. ${ }^{67}$

A. The State agent: witness before entering its function

This exception is the first one contemplated by the Appeals Chamber, which considers that "State agents who, for instance, witnessed a crime before they took office, or found or were given evidentiary material of relevance for the prosecution or the defence prior to the initiation of their official duties [. . .] can legitimately be the addressees of a subpoena" ${ }^{68}$ The non-exercise of an official function at the time when the individual witnesses the facts in question is required for the ICTY to issue him a subpoena duces tecum or a subpoena ad testificandum.

This waiver is akin to the classical exception to jurisdictional immunity since, for example, the Vienna Convention of 1963 on Consular Relations provides for it. Under Article 43 of the Vienna Convention, consular officers enjoy an immunity only for the acts carried out in their official capacity. Actually, the power to issue a subpoena is justified by the lack of direct or indirect connection between the knowledge of the evidence and the present official function of the witness.

B. The State agent in office, casual witness of breaches of international humanitarian law committed by a superior in rank

The Appeals Chamber contemplates this assumption through an example: "a colonel who, in the course of a routine transfer to another combat zone, overhears a general issuing orders aimed at the shelling of civilians or civilian objects. In this case the individual must be deemed to have acted in a private capacity and may therefore be compelled by the International Tribunal to testify as to the events witnessed. By contrast, if the State official, when he witnessed the crime, was actually exercising his functions, i.e., the monitoring of the events was part of his official functions, then he was acting as a State organ

67 See infra-Organisations and their agents-, Part II, Section I.

${ }^{68}$ ICTY Appeals Chamber, October 29th, 1997, Judgement on the Request of the Republic of Croatia for Review of the Decision of Trial Chamber II of 18 July 1997, Prosecutor/ Tihomir Bla·kić, IT-95-14-AR108 bis, para. 49. 
and cannot be subpoenaed, as is illustrated by the case where the imaginary colonel overheard the order while on an official inspection mission concerning the behaviour of the belligerents on the battlefield". ${ }^{69}$ The relevant doctrine unanimously disapproves of this exception, and criticises it either by saying that the assumption is not very convincing ${ }^{70}$ or by describing the Judges' demonstration as "highly artificial". ${ }^{71}$

Indeed, on the one hand, the criterion that deprives the State official of his immunity is not plainly established by the Tribunal. It is clear that the matter at hand involves the circumstances in which the agent witnessed the crimes; however, more precisely, is it the fact of having accidentally heard the order, or of having heard it out of the context of any official capacity? The last sentence of the example inclines the reader to consider that the designation of the colonel as an individual acting in his private capacity seems to proceed from the "routine transfer" since, if he had witnessed the crime during an official mission, he would have lost his official quality. Therefore, the witness' status differs through application of the criterion of the activity during which the individual accidentally witnesses a crime. Indeed, if the agent is not on assignment, he can be issued a subpoena, whereas if he carries on his official function when he hears the order, he enjoys the State agent's immunity.

On the other hand, this hypothesis leads to contemplate two different solutions for the same behaviour of the State official: a field officer who knows that one of his subordinates violated international humanitarian rules has the duty to stop him; otherwise the ICTY has jurisdiction to prosecute him, and if necessary, to sentence him for aiding and abetting: ${ }^{72}$ on the contrary, if the junior officer witnesses such acts committed by his field officer, he is only likely to be subpoenaed.

Therefore, although the exception grants the ICTY the power to issue a subpoena duces tecum or a subpoena ad testificandum to State soldiers, proving the existence of the order remains difficult.

${ }^{69}$ Ibid., para. 50.

${ }^{70}$ Favre (J.-M.), «Le mécanisme du subpoena dans la jurisprudence du Tribunal pénal international pour l'ex-Yougoslavie », Annuaire Français de Droit International, 1997, at 424.

${ }^{71} \operatorname{Bank}(\mathrm{R}$.$) , supra [note 31], at 252$.

72 Article 7 (3) of the ICTY Statute states that "the fact that any of the acts referred to in article 2 to 5 of the present Statute was committed by a subordinate does not relieve his superior of criminal responsibility if he knew or had reason to know tat the subordinate was about to commit such acts or had done so and the superior failed to take the necessary and reasonable measures to prevent such acts or to punish the perpetrators thereof". 


\section{The reluctant State official}

The last assumption which deprives the State agent of his immunity is his refusal to produce the evidence the State agreed to supply concerning a binding order of the Trial Chamber. According to the Appeals Chamber, if the State authorities cannot compel the agent to comply with the order, he would be regarded as an individual acting in his private capacity, and likely to be issued a subpoena. The line of argument of the Appeals Chamber seems contradictory. Although the Judges considered that "the State official is no longer behaving as an instrumentality of his State apparatus", ${ }^{73}$ they allowed the Trial Chamber "to decide whether or not to make a judicial finding of the State's failure to comply with Article 29 [. . .] and ask the President of the International Tribunal to forward it to the Security Council" ${ }^{74}$ Yet, if the State is willing to cooperate with the ICTY and if non-compliance with the binding order arises from the State agent's behaviour, on which grounds may the ICTY consider that the State breached its obligation to cooperate? In spite of this confusing question, the demonstration of the Appeals Chamber is consistent with international legal case-law and codified rules. Two awards stated that the State official's acts although contrary to the given orders - entail their State responsibility. ${ }^{75}$ The International Law Commission also recognises that a State can assume the responsibility for the unlawful acts of his agents. ${ }^{76}$ In consequence, the ICTY drew an exception that grants it the ability not only to report non-compliance by the State of its duty to cooperate, but also to issue a subpoena to the reluctant State official.

${ }^{73}$ ICTY Appeals Chamber, October 29th, 1997, Judgement on the Request of the Republic of Croatia for Review of the Decision of Trial Chamber II of 18 July 1997, Prosecutor/ Tihomir Bla·kić, IT-95-14-AR108bis, para. 51.

${ }^{74}$ Ibidem.

75 The Youmans arbitral award concluded that "there could be no liability whatever for such misdeeds [murders and pillages committed by soldiers] if the view were taken that any acts committed by soldiers in contravention of instructions must always be considered as personal acts", General Claims Commission, November 23rd, 1926, R.S.A., IV, at 116. Likewise, the arbitrators in the Caire case considered that "les deux officiers, même s'ils doivent être censés avoir agi en dehors de leurs compétences [...] et même si leurs supérieurs ont lancé un contrordre, ont engagé la responsabilité de l'Etat, comme s'étant couverts de leur qualité d'officiers et servis des moyens mis, à ce titre, à leur disposition", Claims Commission, June 7th, 1929, R.S.A., IV, at 529-530.

${ }_{76}$ Article 7 of the International Law Commission's Draft Articles on State Responsibility for Internationally Wrongful Acts states that "the conduct of an organ of a State or of a person or entity empowered to exercise elements of the governmental authority shall be considered an act of the State under international law if the organ, person or entity acts in that capacity, even if it exceeds its authority or contravenes instructions". 
Therefore, the broad interpretation of 'individuals acting in their private capacity' allows the ICTY to issue subpoenas to many witnesses, individuals or State officials deprived of their immunity. In addition, this power of the Judges of the ICTY allows them to impose penalties on the witness in case of non-compliance.

Section II. The penalty imposed by the ICTY on individuals in case of noncompliance with a subpoena

The concept of subpoena implies the power to impose a penalty on persons refusing to comply with such orders. Thus, unlike the binding orders issued to States, the subpoena issued to individuals has a criminal nature. ${ }^{77}$ Indeed, any individual who refuses to testify can be sentenced to contempt of the Tribunal under Rule 77 of the RPE (I). Nevertheless, this power of the ICTY is not absolute, since some circumstances exempt individuals from appearing before the ICTY or from producing evidence (II).

\section{Contempt of the Tribunal for non-compliance of the subpoena}

Rule 77 of the RPE introduces into the proceedings of the ICTY the common law concept of contempt of court. This power belongs to any Tribunal and entitles it to punish individuals who refuse to comply or prevent compliance with such a subpoena. This prerogative of the international criminal Judges was contemplated in the United States draft, Article 6.4 of which provided that "contempt of court may be punished by any Chamber of the International Tribunal". ${ }^{78}$ The U.S. experts stressed the importance of such an inherent power to punish the contempt of Tribunal: "[t]he need to maintain the authority and dignity of and respect for the Chambers of the ITand their decrees requires that Chambers have the authority to punish contempt. [. . .] Given the limited subpoena matter jurisdiction of the IT, the contempt power is the only mechanism available to insure the freedom of proceedings from perjury, witness tampering or intimidation and other offences which affect the integrity of the proceedings" ${ }^{79}$ The drafters of the RPE recognised the advisability of such

\footnotetext{
77 Nouvel (Y.), supra [note 40], at 961: “l'ordonnance émise à son endroit [de l'individu] forme un acte contraignant que son inexécution transforme en acte de contrainte".

${ }^{78}$ Suggestions made by the Government of the United States of America, "Rules of Procedure and Evidence for the International Tribunal for the Prosecution of persons responsible for serious violations of international humanitarian law committed in the Former Yugoslavia », November 18th, 1993 [IT/14, November 17th, 1993], at 521.

${ }^{79}$ Ibidem.
} 
a rule and therefore included Rule $77 .{ }^{80}$ Nevertheless, the enforcement of this provision as a consequence of non-compliance of a subpoena by an individual was not obvious in 1997 (A). Moreover, the regulation of the contempt established by the case-law has a peculiarity: the possibility to rule in absentia (B).

\section{A. The enforcement of Rule 77 RPE as a consequence of non-compliance with a subpoena}

In 1997, Rule 77 (A) provided that "a witness who refuses or fails contumaciously to answer a question relevant to the issue before a Chamber may be found in contempt of the Tribunal. The Tribunal may impose a fine not exceeding US \$10,000 or a term of imprisonment not exceeding six months". Two issues may be raised. On the one hand, one could reckon that this rule only contemplated the situation where the witness, who is already present before the Judges, refused to answer their questions. However, in the case of a subpoena, the individual to whom the order is issued may refuse to appear before the Tribunal. Therefore, Professor Klip considers that "it is unclear from the rule whether this part of Rule 77 RPE is applicable to all witnesses, also those still present in their State of residence and unwilling to attend the hearing" ${ }^{81}$ On the contrary, the Prosecutor upholds the idea that "a question relevant to the issue before a Chamber" refers to the global administration of justice. ${ }^{82}$ This is in accordance with the common law system which extends this concept to the "disobedience of a witness order or a witness summons requiring attendance before a court, is liable to punishment by that court 'as if his contempt had been committed in the face of the court'" ${ }^{83}$

On the other hand, the status of 'witness' of the individual subpoenaed is debatable. ${ }^{84}$ However, under a British doctrine, "witnesses may commit a con-

\footnotetext{
${ }^{80}$ Pursuant to Rule 77 of their RPE, the Judges of the ICTR may hold a reluctant witness in contempt of the Tribunal. On the contrary, this power is included neither in the ICC Statute nor in its RPE. And yet, if some penalties are contemplated for the breaches of the administration of justice, the contempt of court is not listed. Nevertheless, the joint reading of Article 70 of the ICC Statute and of Rule 65 of its RPE leads to the tacit existence of such a concept since a reluctant witness may be forced to appear by the Court, under penalties (fine or imprisonment).

${ }^{81}$ Klip (A.), «Witnesses before the International Criminal Tribunal for the former Yugoslavia », International Review of Penal Law, vol. 67, at 276.

${ }_{82}$ Prosecutor's brief in support of subpoena duces tecum, Procureur/Tihomir Bla·kić, April $1^{\text {st }}$, 1997, IT-95-14-PT, para. 6.8, at 36-37.

${ }^{83}$ Ibid., para. 6.9, at 37 quoting The Criminal Procedure (Attendance of witnesses) Act 1965 of the United Kingdom, para. 3.

${ }^{84}$ This argument had been raised by Croatia. Brief of the Republic of Croatia in opposition to subpoena duces tecum, Procureur/Tihomir Bla-kić, May 8th, 1997, IT-95-14-PT, at 38.
} 
tempt in various ways, fail to attend Court or to produce a document without circumstances of justification and in disobedience of a subpoena ad testificandum, a subpoena duces tecum". ${ }^{85}$

In the Bla.kić Case, the Trial Chamber, and then the Appeals Chamber, put an end to those debates, considering that the ICTY was empowered to hold individuals in contempt of the Tribunal when they refused to comply with a subpoena ad testificandum or a subpoena duces tecum. ${ }^{86}$ According to the Judges, this power to sentence a reluctant individual follows from the ontological nature of any court. Furthermore, the existence of this inherent power was demonstrated in 1996, in the Delalić Case, by former President Antonio Cassese: "[t]he Judges acting in plenary had the authority to adopt a rule on contempt only by virtue of this inherent power to control its own proceedings". ${ }^{87}$ The recognition of such an inherent power is in keeping with the logic of modern international law, which admits the existence of implied powers for the carrying out of the mission of international institutions. ${ }^{88}$ One can underline that the phrase 'implied powers' is used for international institutions, whereas the wording 'inherent powers' concerns international tribunals. The former President of the ICTY speaks about the "inherent power to control its own proceedings"; likewise, the ICJ, in 1974, made it clear that it "possesses an inherent jurisdiction enabling it to take such action as may be required, on

${ }^{85}$ Miller (C.J.), Contempt of Court, 1989, at 115, quoted in the amicus brief by Frowein (J. A.), Nolte (G.), Oellers (K.), Zimmermann (A.) for the Max Planck Institute for Comparative Public Law and International Law, Prosecutor/Tihomir Bla·kić, avril 11th, 1997, IT-95-14-PT, para. 6.6., at 36.

${ }^{86}$ ICTY Appeals Chamber, October 29th, 1997, Judgement on the Request of the Republic of Croatia for Review of the Decision of Trial Chamber II of 18 July 1997, Prosecutor/ Tihomir Bla·kić, IT-95-14-AR108bis, para. 59.

${ }^{87}$ ICTY Trial Chamber, November 11th, 1996, Decision on the Prosecutor's motion for the production of notes exchanged between Zejnil Delalić and Mucić, Prosecutor/Zejnil Delalić, Zdrako Mucić a/k/a 'Pavo', Hazim Delić, Esad Landžo a/k/a 'Zenga', IT-96-21-T, para. 33.

${ }^{88}$ The existence of implied powers had been already studied by the PCIJ in 1927, Advisory Opinion of December 8th, 1927, Jurisdiction of the European Commission of the Danube between Galatz and Braila, Series B, vol. 2, $\mathrm{n}^{\circ} 14$, at 6 . Then, the recognition in principle of the existence of UN implied powers had been made by the ICJ in 1949: according to the Court, "[u]nder international law, the Organisation must be deemed to have those powers which, though not expressly provided in the Charter, are conferred upon it by necessary implication as being essential to the performance of its duties. [. . . ] it becomes clear that the capacity of the Organisation to exercise a measure of functional protection of its agents arises by necessary intendment out of the Charter", Advisory Opinion of April 11th, 1949, Reparation for Injuries Suffered in the Service of the United Nations, Rep. 1949, at 182 and 184. See also, ICJ, Advisory Opinion of July 13th, 1954, Effects of Awards of Compensation made by the UN Administrative Tribunal, Rep. 1954, at 56-57. 
the one hand to ensure that the exercise of its jurisdiction over merits, if and when established, shall not be frustrated, and on the other, to provide for the orderly settlement of all matters in dispute" ${ }^{89}$ It follows from this theory of inherent powers that international tribunals do possess powers that allow them to fulfil their mission with efficiency. In the case at hand, the power to punish those in contempt of the Tribunal is necessary to the proper functioning and mandate of the ICTY. Besides, "the Tribunal's inherent power to deal with contempt has necessary existed ever since its creation". ${ }^{90}$ Hence, the Tribunal should have such a jurisdiction all the more because it is "based on the broadest of principles, namely that the courts cannot and will not permit interference with the due administration of justice. The application is universal". ${ }^{91}$ As a consequence of this theory of implied powers and of Article 15 of the Statute that allows them to adopt their own Rules of Procedure, the Judges are entitled to find a individual to be in contempt of the Tribunal when he refuses to comply with subpoena ad testificandum or subpoena duces tecum. Thus, by virtue of this power, the ICTY can guarantee the compliance of its orders, and the efficiency and effectiveness of the administration of justice.

The whole reasoning deriving from the case-law was accepted and codified in the RPE. First, the inherent nature of the power was recognised on November 12th, 1997 by the addition of paragraph (F), which holds that "nothing in this Rule affects the inherent power of the Tribunal to hold in contempt those who knowingly and wilfully interfere with its administration of justice". Second, the ability to punish non-compliance with a subpoena by a declaration of contempt of the Tribunal was expressly admitted, since paragraph (A) (iii) of that Rule stipulates that "[t]he Tribunal in the exercise of its inherent power may hold in contempt those who knowingly and wilfully interfere with its administration of justice, including any person who [. . .] (iii) without just excuse fails to comply with an order to attend before or produce documents before a Chamber". Therefore, pursuant to this inherent power, the violation of a subpoena duces tecum or a subpoena ad testificandum by the addressee could lead to sentencing for contempt of the Tribunal. Thus, unlike

${ }^{89}$ ICJ, Judgement of December 20th, 1974, Nuclear Tests (Australia/France; NewZealand/France), Rep. 1974, at 259 and 463.

${ }^{90}$ ICTY Appeals Chamber, May 30th, 2001, Judgement on Appeal by Anto Nobilo Against Finding of Contempt, Prosecutor/Zlatko Aleksovski, IT-95-14/1-AR77, para. 38.

${ }_{91}$ Court of Appeals of the United Kingdom, 1998, Attorney-General v. Newspaper Publishing PLC, All ER 276, quoted in Prosecutor's brief in support of subpoena duces tecum, Prosecutor/Tihomir Bla·kić, Avril 1st,1997, supra [note 82], para. 6.1, at 34. It is also worth noting that in American law, "the power to punish for contempt is inherent in all courts", Chambers v. Nasco, SDI US 32, at 46. 
States against which the ICTY is not vested with an enforcement power, but merely with the power to make a judicial finding of the State's failure to comply with Article 29 of the Statute, individuals can be subjected to penalties by the ICTY.

\section{B. Both traditional and original proceedings}

The penalty brought upon the reluctant witness and the proceedings of the sentencing for contempt must be analysed. On the one hand, under Rule $77(\mathrm{G})$ of the RPE, "The maximum penalty that may be imposed on a person found to be in contempt of the Tribunal shall be a term of imprisonment not exceeding seven years, or a fine not exceeding 100,000 Euros, or both". The wording of this provision leaves no doubt as to its criminal nature, which echoes back to the criminal nature of the subpoena. Furthermore, in order to ensure the appearance of the individual, the Judges may issue a warrant of arrest that should be executed by the State authorities where the witness lives.

On the other hand, either the Prosecutor or the Trial Chamber propio motu can instigate proceedings for contempt. According to the principle of fair trial, the individual can appeal against the sentencing for contempt. ${ }^{92}$ Beneath this semblance of simplicity, however, lays much complexity. The Appeals Chamber, in the Bla.kic Case, admitted to holding in absentia proceedings. Such a decision is astonishing, as in absentia proceedings are not conceivable for the persons responsible for international crimes. In international criminal law, the appearance of the accused before the tribunal is compulsory ${ }^{93}$ so that the ICTY Statute does not authorise contumacious judgements. ${ }^{94}$ If the accused

${ }_{92}$ Rule 77 (J) of the RPE provides that "[a]ny decision rendered by a Trial Chamber under this Rule shall be subject to appeal". This right of appeal belongs to any accused pursuant to regional and international agreements: Article 14 (5) of the International Covenant on Civil and Political Rights states that "[e]veryone convinced of a crime shall have the right to his conviction and sentence being reviewed by a higher tribunal according to law"; Article 8 (2) (h) of the American Convention on Human Rights "during the proceedings, [every person accused of a criminal offence] has the right to appeal the Judgement to a higher court"; Article 2 of the Protocol ${ }^{\circ} 7$ of the ECHR which orders a "right of appeal in criminal matters".

${ }_{93}$ It is worth pointing out that Article 12 of the Statute of the Nuremberg Tribunal provides for in absentia proceedings in two hypotheses: either the accused had not been arrested, or the interests of justice require it (only Martin Bormann had been condemned in absentia by the Nuremberg Tribunal). However, the ECHR demands that the accused attend its trial. This obligation follows from the object and purpose of Article 6 of the Convention: Judgement of February 12th, 1985, Colozza and Rubinat v. Italy, Series A n ${ }^{\circ} 89$. France was recently blamed for in absentia proceedings: Judgement of February 13th, 2001, Krombach v. France, 29731/96.

${ }_{94}$ The Secretary-General officially spoke against the in absentia proceedings in his Report for the establishment of the ICTY: "A trial should not commence until the accused is physically 
does not appear before the Tribunal - because he escapes the warrants of arrests - the Trial Chamber can only decide "that there are reasonable grounds for believing that the accused has committed all or any of the crimes charged in the indictment"95 and issue an international arrest warrant. Therefore, in absentia proceedings lead neither to a judgement nor a sentencing, but to the issue of a procedural order.

Nevertheless, in the event of a subpoena ad testificandum, non-compliance therewith consists in the non-appearance of the witness. In consequence, the individual to be held in contempt must not be physically present at the hearing. If the in absentia proceedings was not allowed, the ICTY could not compel the witness to appear. As a result, the ICTY should be vested with the power to hold trial by default against individuals falling under its ancillary jurisdiction. At the same time, the individual should also be entitled to minimum procedural guarantees respected by both domestic and international courts and tribunals, in particular, the right to have legal counsel. The Judges in the Bla.kic Case referred to the case-law of the European Court of Human Rights relating to the proceedings: firstly, the waiver of the right to appear before the Tribunal "must be established in an unequivocal manner"; $; 6$ secondly, all available means should be used to find the reluctant witness and to notify him that the hearing will be held; thirdly, the individual must be able to appeal against the judgement held by default. Some people would maintain that the ICTY is not bound by the case-law of a regional court. Nevertheless, as Laurence Sinopoli rightly emphasizes, in order to avoid incompatible State obligations vis-à-vis persons falling within their jurisdiction, international criminal law should abide by the regional conventional guarantees. ${ }^{97}$

present before the International Tribunal. There is a widespread perception that trials in absentia should not be provided for in the statute as this would not be consistent with article 14 if the International Covenant on Civil and Political Rights which provides that the accused shall be entitled to be tried in his presence", Report of the Secretary-General Pursuant to Paragraph 2 of Security Council Resolution 808 (1993), May 3rd, 1993, [UN Doc. S/25704], para. 101. The presence of the accused is also required by Article 20 (4) (d) of the ICTR Statute, and by Article 63 (1) of the Rome Statute. However, it is worth mentioning that the French project for the ICTY Statute made a provision for a trial in absentia in its Article XV (2) [UN Doc S/25266, February 10th, 1993].

${ }^{95}$ Rule 61 (c) of the RPE.

${ }^{96}$ ECHR, Judgement of February 12th, 1985, Colozza and Rubinat v. Italy, Series A n ${ }^{\circ} 89$, paras. 28-29. Case quoted in ICTY Appeals Chamber, October 29th, 1997, Judgement on the Request of the Republic of Croatia for Review of the Decision of Trial Chamber II of 18 July 1997, Prosecutor/ Tihomir Bla·kić, IT-95-14-AR108bis, note 83.

${ }^{97}$ Sinopoli (L.), «Les droits de la défense », in Ascensio (H.), Decaux (E.) and Pellet (A.) (eds), Droit international pénal, CEDIN Paris-X, Pédone, Paris, 2000, at 793 (our translation of 
Otherwise, the individual could turn against the State that cooperates with the ICTY and could charge it with violation of the Convention. Such a situation is manifestly impossible in the instant case, as on the one hand, the Appeals Chamber itself refers to a judgement of the ECHR, and on the other, the RPE codified all these requirements in Rule 77. ${ }^{98}$

Therefore, the ICTY can issue subpoenas to individuals and can impose penalties on them, which it cannot do against States. This differential treatment between private individuals and the State reflects the extant imbalance in international law: whereas the mantle of sovereignty protects States from any penalty, individuals, who do not enjoy that protection, can be subjected to a subpoena. Therefore, individuals seem to be the passive subjects within proceedings of the ICTY: if they are subjects since they vouch for their noncompliance with a binding act, their passiveness finds expression in their quasi-inability to avoid sentencing for contempt by the Tribunal.

\section{The grounds likely to exempt the individual from his or her duty to testify}

Under Rule 77 of the RPE, there is an exception to the power of the ICTY to impose a penalty upon a reluctant witness: "[t]he Tribunal in the exercise of its inherent power may hold in contempt those who knowingly and wilfully interfere with its administration of justice, including any person who [ . . . (iii) without just excuse fails to comply with an order to attend before or produce documents before a Chamber". Consequently, the RPE accepts that certain persons subpoenaed may have legitimate excuses exempting them from complying with the subpoena. These excuses are related to the tenor of the evidence: the subpoenaed individual is not bound to comply with the injunction when the evidence is likely to either penalize him (A) or run counter to the ethics of his functions (B). However, this right is limited since, in reality, the ICTY is entitled to rule on the advisability of the evidence.

\footnotetext{
“afin d'éviter de placer les Etats dans une situation épineuse d'obligations inconciliables vis-à-vis des personnes qui relèvent de leur juridiction, les garanties conventionnelles régionales doivent être respectées par le droit international pénal").

${ }_{98}$ There were paragraphs F, G and J of Rule 77 of the RPE which take up precisely the requirements listed in the ECHR. Yet, unfortunately, the revision of July 29th, 2002 replaces each provision by a general and less-precise paragraph $\mathrm{E}$ which holds that " $\mathrm{t}] \mathrm{the}$ rules of procedure and evidence in Parts Four to Eight shall apply mutatis mutandis to proceedings under this Rule". However, there is no question that the inner meaning of the provision remains the same.
} 
A. The non-compliance of the subpoena vindicated by the possible consequences of testimony on the addressee's situation

Rule 77 must be read in light of Rule 90 (E) of the RPE. An individual subpoenaed can lawfully refuse to comply with the order since "[a] witness may object to making any statement which might tend to incriminate the witness". ${ }^{99}$ This provision comes from a common law principle recognised by various international treaties on human rights. The International Covenant on Civil and Political Rights and the Inter-American Commission on Human Rights ${ }^{100}$ guarantee that no individual can be forced to incriminate himself. Under this right, any individual subpoenaed can refuse to produce evidence that might impair his interests.

Nevertheless, this right is qualified by the next sentence of Rule 90 (E) which provides that " $[\mathrm{t}]$ he Chamber may, however, compel the witness to answer the question". The ICTY is vested with the power to rule on the advisability and the relevance of the reluctant witness' allegation. This provision does not state the justification for allowing the Trial Chamber to compel the witness to appear. However, one can contemplate that the Judges will have to balance the competing interests at stake, i.e., the individual's interests and the interests of a proper administration of justice. If any information held by the witness, albeit prejudicial to his interests, is relevant and likely to help the Tribunal in its prosecution of the international crimes committed in the former Yugoslavia, the Judges may compel the individual to appear (subpoena ad testificandum) or to produce evidence (subpoena duces tecum). On the other hand, when the information is insignificant for the purposes of the trial, the Judges may assert the witness' interests and may accept his non-appearance if those information might incriminate himself. Actually, this exemption from the duty to comply with a subpoena is not absolute but depends upon the Judges' discretionary assessment.

Furthermore, two precise details are left unresolved: on the one hand, under Article 90 (E), "[t]estimony compelled in this way shall not be used as evidence

99 Article 55 (1) of the ICC Statute and Rule 74 of its RPE provide for the same rule.

100 Article 14 (3) (g) of the International Covenant on Civil and Political Rights states that "3. In the determination of any criminal charge against him, everyone [charge with a criminal offence] any shall be entitled [. . .] not to be compelled to testify against himself or to confess guilt"; Article 8 (2) (g) of the American Convention on Human Rights provides that "during the proceedings, every person [accused of a criminal offence] is entitled [. . .] not to be compelled to be a witness against himself or to plead guilty". Two comments should be made: firstly, the ECHR does not contain a similar provision (perhaps because this right comes from the common law and the Convention reflects the continental tradition of human rights); secondly, whereas the whole articles contemplate the assumption of the 'accused', the RPE widens this right to the witnesses. 
in a subsequent prosecution against the witness for any offence other than false testimony". This provision limits the further jurisdiction of the International Tribunal to prosecute the witness for the facts he gave evidence of. Moreover, it grants the witness a feeling of security that urges him to appear and testify. On the other hand, the witness' reluctance to comply with a subpoena ensues from the fact that his testimony 'might tend to incriminate' him. However, doubt remains whether the potential incrimination of the witness should be based upon crimes within the ICTY's jurisdiction (crimes against humanity, genocide, war crimes) or whether it can be based upon other criminal acts within the jurisdiction of the courts of the witness' State (drug trafficking, arms dealing, etc.). In the second assumption, one would have to make sure that domestic legislation ensures that the testimony made before the Tribunal cannot be used against the witness before a domestic court, as otherwise, Rule 90 (E) is rendered useless.

Despite this lingering doubt, the preceding analysis of Rules 77 and 90 (E) of the RPE demonstrates that if the witness has a right of non-compliance, it is very limited since the Trial Chamber can compel the witness to appear if required by the interests of justice. It nonetheless remains that the evidence obtained has a peculiar value because it will not be able to be used against the witness.

\section{B. The privilege against being compelled to testify}

The ICTY articulated two rather similar situations where in articulating privileges against testifying were to be granted: ${ }^{101}$ the interpreter (1) and the war correspondent (2). In both assumptions, the Judges do not grant an absolute immunity to the interpreter and the war correspondent. However, although they recognise that those individuals' profession requires specific treatment, they reserved themselves the power to subpoena them, especially if there is no alternative source of evidence.

1. The impossibility of interpreters of the ICTY to comply with a subpoena In the Delalic case, ${ }^{102}$ the Trial Chamber refused to issue a subpoena ad testificandum to an interpreter. The Defence wanted Mrs Alexandra Pal, an

${ }^{101}$ There is also a absolute immunity for the employee of the Tribunal and of the ICRC, and a privilege for the UNPROFOR. These assumptions will be handled in another article to appear in the same review.

${ }_{102}$ ICTY Trial Chamber, July 8th, 1997, Decision on the Motion Ex Parte by the Defence of Zdravko Mucić Concerning the Issue of a Subpoena to an Interpreter, Prosecutor/Zejnil Delalić, Zdrako Mucić a/k/a 'Pavo', Hazim Delić, Esad Landžo a/k/a 'Zenga', IT-96-21-T. 
interpreter, to appear before the Tribunal to testify upon violation of the rules of proceedings during the cross-examination of the accused. According to the Defence, Alexandra Pal, who attended the cross-examination as an interpreter, became a witness of it. ${ }^{103}$

Under Article 18 and 21 of the Statute, the assistance of an interpreter is a right of the accused. ${ }^{104}$ These articles implement a rule recognised in many legal systems that the accused may have the free assistance of an interpreter if he does not understand or speak the language used in the hearing. ${ }^{105}$ Under Rule 76 of the RPE, ${ }^{106}$ the interpreter, as an unbiased third party, should respect a duty of confidentiality. This obligation is the corollary of his independence and neutrality. Therefore, he cannot disclose the information he had learnt during the exercise of his functions, at the risk of infringing his duty of impartiality. This was the argument invoked by the Trial Chamber to deny its power to issue a subpoena to an interpreter: "in the administration of justice to insulate the interpreter or other functionaries of the International Tribunal from constant apprehension of the possibility of being personally involved in the arena of conflict, on either side, in respect of matters arising from the discharge of their duties". ${ }^{107}$

Nevertheless, the interpreter's capacity to set his duty of confidentiality against a subpoena depends upon another fact. Indeed, in that decision, pronounced ten days after the Bla.kic Judgement of the Trial Chamber II on the subpoena, the Judges elaborated a specific requirement for the issue of a

103 Ibid., para. 5.

104 Article 18 of the Statute provides that: "3. If questioned, the suspect shall be entitled to be assisted by counsel of his own choice, including the right to have legal assistance assigned to him without payment by him in any such case if he does not have sufficient means to pay for it, as well as to necessary translation into and from a language he speaks and understands". Article 21 of the Statute states that: " 4 . In the determination of any charge against the accused pursuant to the present Statute, the accused shall be entitled to the following minimum guarantees, in full equality: [. . .] (f) to have the free assistance of an interpreter if he cannot understand or speak the language used in the International Tribunal".

105 This procedural right is provided by article 14 (3) (f) of the International Covenant on Civil and Political Rights which states that "everyone [charged with a criminal offence] shall be entitled to [.. .] have the free assistance of an interpreter if he cannot understand or speak the language used in court"; Article 6 (3) (e) of the ECHR and article 8 (2) (a) of the American Convention on Human Rights have the same wording.

${ }^{106}$ Rule 76 of the RPE holds that: "Before performing any duties, an interpreter or a translator shall solemnly declare to do so faithfully, independently, impartially and with full respect for the duty of confidentiality".

107 ICTY Trial Chamber, July 8th, 1997, Decision on the Motion Ex Parte by the Defence of Zdravko Mucić Concerning the Issue of a Subpoena to an Interpreter, Prosecutor/Zejnil Delalić, Zdrako Mucić a/k/a 'Pavo', Hazim Delić, Esad Landžo a/k/a 'Zenga', IT-96-21-T, para. 20. 
subpoena to an interpreter. According to the Judges, "[to subpoena an interpreter] should not be encouraged where other ways exist for the determination of the issue". ${ }^{108}$ Therefore, if a different and less restrictive method enables the Judges to obtain the same evidence, it should be favoured. However, in the specific case, "[t]he Trial Chamber was not persuaded by the contention of defence counsel that the only way to fill the gap created by any omissions in the proceedings is through testimony of the interpreter. The suggestion made to counsel during oral argument that the issue can be ascertained and the omission rectified through proper cross-examination of the other parties present during the alleged questioning". ${ }^{109}$ Eventually, in the Delalic case, the existence of another method to obtain evidence enables the interpreter to protect his obligation of confidentiality. There is no doubt that if the subpoena ad testificandum would have been the only way to get the information, Mrs Pal would have been obliged to comply with the subpoena.

\section{The status of war correspondents}

Between 2002 and 2003, within the framework of the Krajina case, ${ }^{110}$ the ICTY has been confronted with a war correspondent's refusal to appear to give evidence. The issue lies in the fact that Jonathan Randal, a war correspondent of the Washington Post, published an article ${ }^{111}$ which contains quotes attributed to the accused, Radoslav Brdjanin, and, whereas he published this article, he refused to comply with a subpoena ad testificandum. Two stances could be drawn: on the one hand, to subpoena a journalist would tend to undermine his independence, jeopardise his sources, and ultimately reduce the amount of information available about international crimes. Therefore, the second stance remains, where, unless the war correspondent consents to testify voluntarily, ${ }^{112}$ he should enjoy a "qualified privilege [. . . not to be compelled to testify about [his] newsgathering". ${ }^{113}$ On the other hand, as the testimony sought affects

108 Ibidem.

109 Ibid., para. 15.

110 There were three decisions of the ICTY regarding this issue: Trial Chamber II, June 7th, 2002, Decision on Motion to Set Aside Confidential Subpoena to Give Evidence, Prosecutor/Radoslav Brdjanin and Momir Talic, IT-99-36-T; Appeals Chamber, December 11th, 2002, Decision on Interlocutory Appeal, Prosecutor/Radoslav Brdjanin and Momir Talic, IT-99-36-AR73.9; Trial Chamber II, June 30th, 2003, Decision on Prosecution's Second Request for a Subpoena of Jonathan Randal, Prosecutor/Radoslav Brdjanin, IT-99-36-T.

111 The article entitled "Preserving the Fruits of Ethnic Cleansing; Bosnian Serbs, Expulsion Victim See Campaign as Beyond Reversal" was published on February 11th, 1993.

112 Some war correspondents did testify on a voluntary basis: E.G. Martin Bell and Jacky Rowland, both from the BCC, and Ed Vulliamy from The Observer/Guardian.

113 This was Randal's thesis: ICTY Trial Chamber II, June 7th, 2002, Decision on Motion to 
already-published materials, there is no need to consider that the subpoena would jeopardise the information and therefore the privilege is not relevant. In their decision, the argument of the Judges of the Appeals Chamber was as follows: firstly, they considered that war correspondents serve public interest; ${ }^{114}$ secondly, although they admitted that a subpoena may affect the journalists' ability to carry out their work, a balance of interests was deemed necessary. Thus, among the three tests suggested by Jonathan Randal, ${ }^{115}$ the amici curiae ${ }^{116}$ and the Trial Chamber, ${ }^{117}$ the Judges of the Appeals Chamber chose a balancing approach, between the interests of justice (to have all the elements to assess the defendant's culpability) and the public interest in the work of war correspondents (to gather all the adequate information to let the international community know about issues of public concern). Moreover, they added that

Set Aside Confidential Subpoena to Give Evidence, Prosecutor/Radoslav Brdjanin and Momir Talic, IT-99-36-T, para. 12. See also the stance of the amici curiae before the Appeals Chamber who consider that a subpoena "will rob war correspondents of their status as observers and transform them into participants, undermining their credibility and independence and thus their ability to gather information”, ICTY Appeals Chamber, December 11th, 2002, Decision on Interlocutory Appeal, Prosecutor/Radoslav Brdjanin and Momir Talic, IT-99-36-AR73.9, para. 18.

${ }^{114}$ ICTY Appeals Chamber, December 11th, 2002, Decision on Interlocutory Appeal, Prosecutor/Radoslav Brdjanin and Momir Talic, IT-99-36-AR73.9, para. 36. See also the Written Submissions on Behalf of Jonathan Randal to Set Aside Confidential Subpoena to Give Evidence, where the journalist explains that war correspondents "play a vital role in bringing to the attention of the international community the horrors and reality of conflict", May 8th, 2002, para. 41.

115 According to the journalist, there should be a balance of interests not taking into account the mere pertinence of the evidence but determining that the evidence: "(1) is of "crucial importance' to determining a defendant's guilt or innocence; (2) cannot be obtained 'by any other means or from any other witness'; (3) will not require the journalist to breach any obligation of confidence; (4) will not place the journalist, his family, or his sources in reasonably apprehended personal danger; (5) will not serve as a precedent that will 'jeopardise the effectiveness or safety of other journalists reporting from that conflict zone in the future", ICTY Appeals Chamber, December 11th, 2002, Decision on Interlocutory Appeal, Prosecutor/Radoslav Brdjanin and Momir Talic, IT-99-36-AR73.9, para. 15.

116 As for the amici curiae, they suggested two requirements to issue a subpoena to a war correspondent: "(1) the testimony is essential to the determination of the case (its contribution to the case must be critical to determining the guilt or innocence of a defendant); and (2) the information cannot be obtained by any other means", ICTY Appeals Chamber, December 11th, 2002, Decision on Interlocutory Appeal, Prosecutor/Radoslav Brdjanin and Momir Talic, IT-99-36AR73.9, para. 20.

${ }^{117}$ In its decision of June 7th, 2002, the Trial Chamber considered that since the testimony was relevant and pertinent to the case, the subpoena could be issued. See ICTY Trial Chamber II, June 7th, 2002, Decision on Motion to Set Aside Confidential Subpoena to Give Evidence, Prosecutor/Radoslav Brdjanin and Momir Talic, IT-99-36-T, para. 32. 
if there is an alternative source to obtain the evidence sought, the Trial Chamber should choose it. In consequence, "in order for a TC to issue a subpoena to a war correspondent a two-pronged test must be satisfied. First, the petitioning party must demonstrate that evidence sought is of direct and important value in determining a core issue in the case. Second, it must demonstrate that the evidence sought cannot reasonably be obtained elsewhere". ${ }^{118}$ Eventually, the subpoena was denied by Trial Chamber II in June 2003 on the ground that the first standard (the probative value of the testimony ${ }^{119}$ ) was not satisfied.

Judge Shahabuddeen gives a special meaning to the balancing of interests, since, according to him, the problem consists in determining whether the restriction of freedom of expression is necessary or not. He wonders whether "the harm resulting from the withholding of the evidence to the public interest in the administration of justice [is] greater than the harm resulting from the giving of evidence to the public interest in the free flow of information which underlies freedom of expression". ${ }^{120}$ Concerning the second standard then, he deems that there is another source of evidence: $\mathrm{Mr}$ ' $\mathrm{X}$ ', who was present at the interview, understood the language of the conversation. Judge Shahabuddeen considered that despite his quality of war correspondent, he represented another likely source of evidence. Nevertheless, it is worth underlying that $\mathrm{Mr}$ ' $\mathrm{X}$ ', being a war correspondent, might be entitled to the same qualified privilege. Consequently, this so-called other source of evidence is not of great use for the Tribunal since, in practice, the same problem might arise.

One has to qualify the scope of this case-law since it concerns testimony on published material. Indeed, the journalist or war correspondent might be acquainted with some crimes within the jurisdiction of the ICTY but without having written on them. Thus, the question is raised as to which standard should be required in case of unpublished material. The reasoning of the Appeals Chamber is no longer relevant to this question, as it was based on the

${ }^{118}$ ICTY Appeals Chamber, December 11th, 2002, Decision on Interlocutory Appeal, Prosecutor/Radoslav Brdjanin and Momir Talic, IT-99-36-AR73.9, para. 50.

119 This criterion is not specific to the issuance of a subpoena to a war correspondent since it appears in Rule 89 (c) and (d) of the RPE: "(C) A Chamber may admit any relevant evidence which it deems to have probative value. (D) A Chamber may exclude evidence if its probative value is substantially outweighed by the need to ensure a fair trial". In consequence, this standard is required for any kind of evidence. Nevertheless, with regard to the subpoena ad testifican$d u m$, the relevance of the testimony is of great importance because the imposition of a criminal sanction in case of non-compliance is at stake.

${ }^{120}$ Separate Opinion of Judge Shahabuddeen, December 11th, 2002, Decision on Interlocutory Appeal, Prosecutor/Radoslav Brdjanin and Momir Talic, IT-99-36-AR73.9, para. 11. He considers that this condition was not satisfied. 
existence of a published article. There is no doubt that, if need be, the war correspondent should enjoy a privilege and a stricter balance of interest should be required for the issue of a subpoena: the criterion of relevance being too weak, the unpublished testimony should be "crucial to determine guilt or innocence". ${ }^{121}$ Thus, even if the Judges should still look first to another source of evidence, on the other hand, they would be entitled to subpoena the war correspondent only if it is exigent for the proper administration of justice (and not just determinative for the outcome of the case).

The ultimate purpose of the ICTY is to ensure both a fair trial and an efficient administration of justice. From these cases, one can stress the rule that "it is for the Tribunal to determine the balance between the need for disclosure and the need for non disclosure, using the interests of justice as a criterion". ${ }^{122}$ The balance of the interests, here, relies in addition upon an external factor: the existence of another method to get the evidence. Therefore, if the interest of justice is that the interpreter or the war correspondent testify and if there are insufficient means at the disposal of the ICTY, the subpoenaed interpreter or war correspondent will have to comply with the subpoena.

\section{Part II. Proceedings dependent upon States}

If the Judges of the ICTY control subpoena proceedings - owing to their broad interpretation of 'individuals acting in their private capacity', and their power to impose penalties in case of non-compliance with orders - the proceedings, however, remain dependent upon States.

Beginning in 1907, the Hague Convention for the Pacific Settlement of Disputes compelled States to "undertake to make use of the means at their disposal, under municipal law, to insure the appearance of the witnesses or experts who are in their territory". ${ }^{123}$ Likewise, the methods of State cooperation vis-à-vis the ICTY and related to compliance with the subpoena rely upon the domestic implementing legislation of each individual State. ${ }^{124}$ This subordination of the proceedings to the will of States demonstrates the lack of plenary

${ }^{121}$ Separate opinion of Judge Chikako Taya, June 30th, 2003, Decision on Prosecution's Second Request for a Subpoena of Jonathan Randal, Prosecutor/Radoslav Brdjanin, IT-99-36-T, para. 8 [emphasis added].

${ }^{122}$ Hampson (F. J.), «The International Criminal Tribunal for the Former Yugoslavia and the Reluctant Witness », International and Comparative Law Quarterly, 1998/1, at 62.

${ }^{123}$ Quoted by Anderson (C. P.), «Production of Evidence by Subpoena before International Tribunals », American Journal of International Law, 1933, at 498.

${ }^{124}$ The obligation for States to enact legislation to assist the international courts in enforcing subpoenas appeared in Article XII of the bilateral treaty between United States and United Kingdom of January 11th, 1909. This provision states: "All parties interested therein shall [. . . ] 
legal personality of individuals. The addressees of a subpoena ad testificandum or a subpoena duces tecum are only intermediate subjects of international law ${ }^{125}$ to ensure that the ICTY is prevented from establishing direct relations with them. Indeed, service of the subpoena depends on the primary subjects of international law-States (Section I). In addition, State organs are the auxiliary of the ICTY to enforce the compliance of the subpoena issued to their residents (Section II), notwithstanding the latter's inability to control or otherwise supervise them.

\section{Section I. The service mechanism for the subpoena}

As with any other judicial order, service of a subpoena should be effected personally on the witness. Nevertheless, as it is an order from an international entity issued to a subject of domestic law, service of the subpoena cannot follow the traditional proceedings inherent to the direct service of orders (I). However, there is an exception to the principle of indirect service of the procedural orders of the ICTY: the Appeals Chamber, in the Bla-kić Case, admitted the possibility of an ad personam service of orders without the State intermediary (II).

\section{The principle allowing for indirect service of the subpoena}

The probationary system of the ICTY shows that individuals-witnesses do not enjoy plenary international legal personality, so that orders issued to them must pass through the authorities of their national State. Indeed, the Judges of the ICTY have recognised that the Trial Chamber "will normally turn, once again, to the national authorities for their cooperation". ${ }^{126}$ The search for the State

adopt such legislation as may be appropriate and necessary to [. . . ] provide for the issue of subpoenas for compelling the attendance of witnesses in proceedings before the commission", in Anderson (C. P.), ibid.

125 This lack of immediacy of individuals in the international legal order may be illustrated by the mechanism of diplomatic protection. In the framework of this legal fiction, the State, espousing the cause of its citizen as the injured party, intervenes in its own name when it feels that a rule of conventional or customary international law has been violated. The basis for diplomatic protection was expounded by the Permanent Court of International Justice in the Mavrommattis case: "By taking up the case of one of its subject and by resorting to diplomatic action or international judicial proceedings on his behalf, a State is in reality asserting its own rights - its right to, ensure, in the person of its subjects, respect for the rules of international law", Judgement of August 30th, 1924, The Mavrommattis Palestine Concessions (Greece/United Kingdom), PCIJ Rep. Series A, ${ }^{\circ}$ 2, at 12.

${ }^{126}$ ICTY Appeals Chamber, October 29th, 1997, Judgement on the Request of the Republic 
cooperation to serve the subpoena follows from the secondary quality of individual addressees in the international legal order, who need the supervision of States. It is a principle of international procedural law ${ }^{127}$ that international Judges make their service conveyances through national authorities. These procedures were used by the ICTY many times: in the Delalic Case, the Trial Chamber issued a subpoena ad testificandum to five witnesses and, at the same time, demanded that the Bosnian government serve this order on addressees or resident in its territory. ${ }^{128}$ A preceding decision of the Tribunal, in the Bla.kic Judgement of the Appeals Chamber, was confirmed by this Judgement, which stated that "any order or request of the International Tribunal should be addressed to a specific central body of the country". ${ }^{129}$ The further orders of the ICTY were consistent with this case. For example, in 1998, the Judges, quoting the Judgement of October 29th, 1997, issued a subpoena duces tecum to some witnesses and requested the Bosnian government to serve it on the individuals concerned. ${ }^{130}$

Despite this recognition of the possibility of indirect service of subpoena documents, the Judges of the ICTY seem to regret that this principle appears in some domestic implementing legislation. Several national laws confirm that the ICTY orders should be issued to a national authority appointed under the relevant domestic law, who will be responsible for conveying it to the final addressee. Thus, Article 6 of the Finnish law provides that "Finnish courts and

of Croatia for Review of the Decision of Trial Chamber II of 18 July 1997, Prosecutor/ Tihomir Bla·kić, IT-95-14-AR108bis, para. 55.

${ }^{127}$ See Article 44 of the ICJ Statute: "For the service of all notices upon persons other than the agents, counsel, and advocates, the Court shall apply direct to the government of the state upon whose territory the notice has to be served". Likewise, Article 52 (2) (e) of the Rules of the International Tribunal for the Law of the Sea enjoins the Tribunal to "direct all communications through the Government of the State in whose territory the communication has to be received". On the contrary, the Rome Statute is equivocal: although it contemplates the direct service of the summon issued to the accused (Article 58 (7)), it nevertheless requires State cooperation for the "service of documents" (Article 93 (1) (d)).

${ }^{128}$ Points 3 and 4 of the Pronouncement of the Order of Trial Chamber II, October 16th, 1997, Ordonnance relative à la requête du Procureur concernant la délivrance d'injonctions aux fins de témoigner et d'une ordonnance décernée au Gouvernement de Bosnie-herzégovine, Procureur/Zejnil Delalić, Zdrako Mucić a/k/a 'Pavo', Hazim Delić, Esad Landžo a/k/a 'Zenga', IT-96-21-T.

${ }^{129}$ ICTY Appeals Chamber, October 29th, 1997, Judgement on the Request of the Republic of Croatia for Review of the Decision of Trial Chamber II of 18 July 1997, Prosecutor/ Tihomir Bla-kić, IT-95-14-AR108bis, para. 54.

${ }^{130}$ ICTY Trial Chamber, June 25th, 1998, Ordonnance relative à la requête de la défense de Hazim Delic aux fins de décerner des injonctions à produire, Procureur/Zejnil Delalić, Zdrako Mucić a/k/a 'Pavo', Hazim Delić, Esad Landžo a/k/a 'Zenga', IT-96-21-T. 
other competent authorities shall provide such legal assistance as the Tribunal requests in the service of [...] summons". Pursuant to its Article 25, the Croatian legislation also contemplates the intermediary role of the national organs for the service of the subpoena, since it holds that "[a]t the Tribunal's request, the competent authorities of the Republic of Croatia shall [. . .] deliver the summons and other documents sent by the Tribunal to persons resident in the Republic of Croatia". Eventually, under Article 35 of the implementing law of New Zealand, the authorities help to serve the procedural acts of the ICTY. The Bla kić Judgement of the Appeals Chamber criticises these legislative provisions because "these laws tend to apply to the relations between national authorities and the International Tribunal the same approach that they normally adopt in their bilateral or multilateral treaties of judicial cooperation". ${ }^{131}$ These laws are actually typical of the horizontal State-relationship, whereas the relationship between the States and the ICTY is of a vertical nature, which in theory should allow the Tribunal to issue subpoenas directly to the witnesses. Nevertheless, although the ICTY blames States for having established this precedent for the indirect service of orders, it recognises and applies it. Thus, the ICTY seems to simultaneously state both its inability and its dependence upon national authorities relating to the service of subpoenas. This has lead the Judges to introduce two exceptions to the principle of indirect service of $s u b$ poena ad testificandum and subpoena duces tecum.

\section{The hypothesis of immediate service of the subpoena}

The principle of indirect service of documents does not apply anymore as soon as either the domestic legislation of the individual's State of residence allows an immediate service of acts (A) or this State declines to cooperate with the $\operatorname{ICTY}(B)$.

A. The direct service of subpoenas provided for in the national implementing laws

In the Bla.kic Case, the Appeals Chamber stated that "the International Tribunal may enter directly into contact with a private individual [. . .] when

${ }^{131}$ ICTY Appeals Chamber, October 29th, 1997, Judgement on the Request of the Republic of Croatia for Review of the Decision of Trial Chamber II of 18 July 1997, Prosecutor/ Tihomir Bla·kić, IT-95-14-AR108bis, para. 54. For instance, this is worth mentioning the Convention on the Service Abroad of Judicial and Extrajudicial Documents in Civil or Commercial Matters of November 15th, 1965. The principle adopted is of semi-direct forwarding, provided by the designated Central Authority. 
this is authorised by the legislation of the State concerned". ${ }^{132}$ Although this exception exists, its scope remains limited since only two domestic laws allow the Tribunal to serve the subpoena on its addressee without the intervention of State organs. The first one is the Austrian Federal Law, whose Article 11 (1) holds that "[t]he International Tribunal shall have the authority to forward a summons and other documents to persons in Austria directly by post". The second one is the Swiss Federal order, which provides under its Article 23 that "[p]rocedural formalities and judicial decisions of the international tribunals may be served by mail directly to the addressee in Switzerland". Moreover, another law is quoted by the Appeals Chamber in the Bla.kic Case - the German law - but it does not explicitly vest the ICTY with the power to serve a subpoena directly on an individual. The Judges' assertion is based upon the interpretation of Article 4 (2) of the German law ${ }^{133}$ made by Prof. Frowein in the amicus brief for the Max Planck Institute. According to him, "this formula indicates that the [International] Tribunal may directly summon individuals". ${ }^{134}$ The German legislation may implicitly entitle the ICTY to undertake the direct service of orders. Furthermore, the Judges considered that Article 8 of the Finnish Act enables them to serve a subpoena on individuals. ${ }^{135}$ However, nothing in this provision suggests such an intention of the Finnish legislators; the ICTY tried to extend its power of direct service of subpoenas without making sure that Finland actually allowed it.

Therefore, only two domestic implementing laws - of Austria and Switzerland - undoubtedly entitle the Tribunal to serve its orders directly on the witnesses. Thus, this power is not inherent to its functions but follows from national legislations: without an appropriate domestic provision, direct service of the subpoena is not possible.

${ }^{132}$ ICTY Appeals Chamber, October 29th, 1997, Judgement on the Request of the Republic of Croatia for Review of the Decision of Trial Chamber II of 18 July 1997, Prosecutor/ Tihomir Bla·kić, IT-95-14-AR108bis, para. 55.

133 Article 4 (2) of the German law provides that: "Should the Tribunal require the personal appearance of a person [. . . ], the same legal means may be employed to ensure their appearance as would be permissible in the case of a summons to appear before a German court or a German public prosecutor".

${ }^{134}$ Amicus brief by Professors Frowein (J. A.), Nolte (G.), Oellers (K.), Zimmermann (A.) for the Max Planck Institute for comparative public law and international law, Prosecutor/Tihomir Bla·kić, supra [note 85], at 45.

135 This provision states that "A witness or an expert who is in Finland and has been summoned to appear before the Tribunal, is under a duty to comply with the summons". 
B. Direct service of the subpoenas owing to the lack of cooperation of the individual's State of residence

The ICTY Appeals Chamber outlined another case for the immediate service of orders "when the authorities of the State or Entity concerned, having been requested to comply with an order of the International Tribunal, prevent the International Tribunal from fulfilling its functions". ${ }^{136}$ It is obvious that if the State concerned refuses to cooperate with the service of the Tribunal's orders, the witness will never be aware of the subpoena; however, the Tribunal needs evidence to fulfil its mission. Therefore, the ICTY must be vested with the power to serve the subpoenas directly to an individual in cases where a reluctant State is involved. This power had been stressed by the Prosecutor who stated that "[si] nous avons des raisons de croire que le témoin serait prêt à exécuter l'ordonnance mais que l'Etat, soit en raison de sa législation soit de son attitude, [ . . . n'est pas disposé à aider, [ . . .] nous aurions incontestablement le droit de nous adresser directement à cette personne. Par courrier, ce serait préférable". ${ }^{137}$ Such proceedings has been used in the Tadić case, since Judge McDonald had issued summons which had then been personally handed to their respective addressees. ${ }^{138}$

In addition, if the State refuses to serve the subpoena on an individual residing on its territory, the State has failed to comply with its obligation to cooperate with the ICTY. Thus, the Trial Chamber would be entitled to make a judicial finding to that effect and report this failure to the Security Council, which might, in turn, impose sanctions on the reluctant State.

However, what happens if, de facto, the State does not have any authority over certain parts of its territory? The unwillingness of the State is not the source of the problem; rather, it is its factual inability which precludes service. As Professor Bank suggests, ${ }^{139}$ the ICTY would, in that eventuality, be entitled to issue a subpoena directly to the witness. For example, in the SerbiaMontenegro, the Government had no authority over the Province of Kosovo, which is part of its territory. In such a hypothesis, it would be ineffectual for the ICTY to request the Yugoslav organs to serve a subpoena on an individual

${ }^{136}$ ICTY Appeals Chamber, October 29th, 1997, Judgement on the Request of the Republic of Croatia for Review of the Decision of Trial Chamber II of 18 July 1997, Prosecutor/ Tihomir Bla·kić, IT-95-14-AR108bis, para. 55.

${ }_{137}$ Transcript of the ICTY Appeals Chamber, September 22nd, 1997, Prosecutor/Tihomir Bla-kić, IT-95-14-AR108bis, at 120.

${ }^{138}$ In this case, it was a question of summons and not subpoenas; nevertheless, what applies for summons applies all the more to subpoenas, given the latter's binding nature. ICTY Trial Chamber, August 20th, 1996, Summons before a Trial Chamber, Prosecutor/Du $\cdot k o$ Tadić a/k/a Dule, IT-94-1-T.

139 Bank (R.), supra [note 31], at 254. 
who lives in Kosovo. In addition, the Tribunal could not ask for the cooperation of this province, which, devoid of international legal personality, is therefore not bound with the duty to assist the Tribunal for the former Yugoslavia. Therefore, the ICTY should be allowed to serve a subpoena directly on its addressee.

In consequence, the principle of indirect service of subpoenas admits three exceptions: a subpoena may be issued to individuals without a State intermediary when: (1) the domestic legislation provides for it; (2) the national authorities fail to cooperate with the Tribunal for the service of the subpoena; and (3) de facto the State does not exercise its authority over the part of its territory where the witness has sought refuge. Apart from these situations, the rule remains one of indirect service of the subpoena through national organs. ${ }^{140}$ Besides, the State cooperation related to the subpoena also affects their compliance.

\section{Section II. Compliance with the subpoena}

Whereas the service of the subpoena can be made without State intervention, compliance therewith is entirely dependent upon State authorities. The subpoenaed individual has to appear before the ICTY in order to testify or to produce evidence, and his State of residence has to make sure the individual does comply with the subpoena. However, the difficulties that might arise are twofold: either the witness refuses to appear before the Tribunal, or the State authorities prevent him from appearing. In case of a reluctant witness, the ICTY may hold the individual in contempt of the Tribunal but the concrete compliance of the subpoena - the appearance of the witness - depends on his State of residence (I). In case of a reluctant State, its refusal does not neutralise the proceedings for good as the Tribunal has evolved procedural mechanisms that permit to circumvent the State reluctance (II).

\section{The State as an auxiliary for compliance with the subpoena}

Article 9 (3) of the ICTY Guidelines encourages States to include in their domestic legislation a stipulation to the effect that "[a]nyone who is summoned

140 This indirect service of documents is shared by the other procedural orders the International Tribunal can issue to individuals. However, this mechanism has a special scope as concerns the subpoena, whose comminatory nature leads to a fast answer, although the immediate service of subpoenas could be more relevant in order to obtain the appearance of a witness or the production of documents. Nevertheless, passing in transit through State authorities, the State remains well-informed about the subpoena and may control compliance by its addressee therewith. 
by a Judge or Trial Chamber of a tribunal to appear as a witness or expert shall comply with the summons". ${ }^{141}$ This provision implies that the relevant national laws should oblige the subpoenaed witness to comply with the order. In addition to this obligation for the witness, Article 9 (1) of these Guidelines urges the State organs to lend their cooperation to the ICTY for the production of evidence. ${ }^{142}$ The State of residence becomes the auxiliary of the ICTY to ensure their testimony. This State cooperation assumes two aspects, each complementing the other: on the one hand, the State can facilitate the witness' appearance before the International Tribunal (A); on the other, State authorities may compel the witness to appear (B). One must emphasise that the implementing legislations do not contemplate the same ways of assistance so that the status of the subpoenaed witness is not even.

\section{A. The assistance offered to subpoenaed individuals}

The subpoenaed witness may be reluctant to appear before the Tribunal for financial reasons. The journey to The Hague may represent insurmountable financial burdens for certain witnesses. However, as fundamental notions of justice preclude acceptance by the ICTY of losing testimony for merely material considerations, some national legislations make provision for financial support, whose object varies depending on the State.

On the one hand, some domestic laws provide that the amount to be granted cover the entirety of the expenses related to the witness' travel. Only two European States lavish this generous and unconditional aid on the witnesses: Article 7 (2) of the Spanish law explicitly holds that "[t]he Ministry of Justice shall advance the expenses necessary for such appearance"; likewise, Article 10 (7) of the Italian law provides that " $[t]$ he costs for the coercive accompaniment shall be paid by the State". In Spain and in Italy, the subpoenaed individual enjoys a right to unconditional compensation so as to facilitate and encourage compliance with the order.

On the other hand, in some domestic legislation, the witness' request and/or his effective appearance before the International Tribunal is required for him to obtain the financial support. The Austrian law, under Article 11 (2), provides

\footnotetext{
141 Tentative Guidelines for National Implementing Legislation of United Nations Security Council resolution 827 of 25 May 1993, sent by the President of the Yugoslavia Tribunal to Members of the United Nations on 15 February 1995, reprinted in Amnesty International, The international criminal tribunals: Handbook for government cooperation - Supplement One (AI Index: IOR 40/08/96), Part V.

${ }^{142}$ This provision states: "[ $t$ ]he legislation should provide that courts or other competent authorities will provide all necessary assistance at the request of the tribunals for the identification, location and interviewing of witnesses in the state".
} 
that "[a]t the request of the International Tribunal, the Austrian court shall remit an appropriate travel advance to witnesses [. . . ] summoned to appear before the Tribunal should such persons request this payment. The advance shall be reclaimed if the witness [...] fails to attend the hearing of the International Tribunal or in some other way fails to discharge the duties upon which their summons was predicated". Finland contemplates a step of the same kind for the subpoenaed witness: Article 9 (1) of its implementing Act holds that "[a] witness [. . .] summoned in Finland to appear before the Tribunal shall, upon request, be granted advance payment". In these hypothesis, the financial support is not automatic, as it is granted only if the witness requests it or in fact appears before the Tribunal. One must admit that the second requirement (compliance with the order) is legitimate, but to require an active step from the witness to obtain financial support is likely to hinder the testimony. Indeed, witnesses usually take refuge in a State ${ }^{143}$ so that they do not have the essential knowledge to carry out the administrative requirements, especially some linguistic problems.

Finally, some legislation remains uncertain as for the scope of the compensation planned: the Swedish Act provides, in its Article 15, for the right to support for all the witnesses living in Sweden and subpoenaed by the ICTY; however, the provision does not state precisely whether the compensation covers the whole of the costs related to compliance with the subpoena. Some other laws remain uncertain as regards even the possibility for the witness to enjoy such financial support, such Article 4 of the Hungarian Act, which remains deliberately obscure. If it ensures that "[t]he expenses incurred in Hungary concerning the application of this Act shall be borne by the State", it is neither obvious nor certain that this provision concerns the costs related to the appearance of a subpoenaed witness. In addition, the expression "expenses incurred in Hungary" seems to exclude any expense that would occur outside Hungary: such a provision is not very favourable to the subpoenaed witness, especially when he has to appear before the Tribunal, in The Hague. The U.S. legislation is also nebulous: Article 5 of its implementing act provides that "the United States shall pay all costs associated with a surrender proceeding except for the translation of documents and the transportation of the person surrendered, but it permits the United States and the tribunals to agree otherwise". ${ }^{144}$ Therefore,

143 Between 250.000 ( «Help Migrants », Financial Times, February 17th, 1993, at 17) and 400.000 (Crane-Engel (M.), « Germany vs. Genocide », New York Times, October 30th, 1994, at 56) Yugoslav refugees are estimated to have been welcomed into Germany. Furthermore, 3,700 Bosnians emigrated to the United States.

144 Amnesty international On-Line, International Criminal Tribunals: Handbook for Governments Cooperation, August 1st, 1996, [www.web.amnesty.org/ai.nsf/index/I OR400071996]. 
if the American government does not have the duty to assume the cost of the compliance of a subpoena issued to one of its residents, it can, at its sole discretion, decide to assume them.

This analysis of the national implementing legislations regarding the financial support granted to the subpoenaed witness attests to the deep disparity between the witnesses' relative situations. Despite the Guidelines of 1993 which request States to provide assistance for the Tribunal in complying with subpoenas, the result is hardly satisfactory. If some laws contemplate financial support, other States remains equivocal or even silent - as does the French law, where no provision tackles this issue. ${ }^{145}$ In order to prevent such an iniquity, Article 100 of the ICC Statute holds that the costs concerning the witnesses will be assumed by the Court. This centralisation will help to avoid the national disparities that lead to an inequality between the witnesses as their place of residence may be. Without such a rationalisation within the ICTY Rules, financial support remains dependent upon whims of the domestic legislator.

\section{B. State's sanction of the reluctant witness}

In addition to this financial support, legal aid is supplied by the States. Whereas in cases of financial difficulty, the subpoenaed witness is willing to comply with the order but is confronted with financial obstacles, the hypothesis of State legal aid concerns the reluctant witness for legal reasons.

If the ICTY is vested with the power to hold reluctant witnesses in contempt of the Tribunal even in absentia, recognition of this fact does not lead to the concrete appearance of the subpoenaed individual before the Tribunal. The cooperation of the addressee's State of residence therefore becomes absolutely necessary. This State collaboration with the ICTY is two-fold: firstly, the State can force the witness to appear before the ad hoc Tribunal (1); and secondly, it may impose penalties on him (2).

\section{The duty to appear}

Under the relevant international conventions and domestic legislation, the State authorities have the duty to force the witness to comply with the subpoena.

Firstly, pursuant to Rule 90bis of the RPE, when the subpoenaed witness is detained in a State, that State must transfer him to the ICTY. One must concede that Article 29 of the ICTY Statute, which is the legal justification for the State

${ }^{145}$ It is worth noting that, on the contrary, Article 9 of the Turkish law considers that the transportation and accommodation costs of the witnesses who appear before the International Tribunal should be borne by the ICTY pursuant to Article 32 of its Statute. 
duty to cooperate, does not contemplate this obligation. It only requests the State to transfer the person accused of committing serious violations of international humanitarian law. Nevertheless, the details of implementation of the duty to collaborate enumerated by Article 29 are not exhaustive, considering the phrase "but not limited". Thanks to this flexibility, in 1995, the Judges added Rule 90bis, which provides in paragraph A that "[a]ny detained person whose personal appearance as a witness has been requested by the Tribunal shall be transferred temporarily to the detention unit of the Tribunal, conditional on the person's return within the period decided by the Tribunal". This provision must be read together with Rule 56 of the RPE, which states that "[t] he State to which a warrant of arrest or a transfer order for a witness is transmitted shall act promptly and with all due diligence to ensure proper and effective execution thereof, in accordance with Article 29 of the Statute". It follows from this combination of Rules 90 bis and 56 of the RPE that State authorities have the duty to transfer the detained witness to the ICTY. ${ }^{146}$

Secondly, this obligation also appears in some national implementing legislations which strengthen his binding nature. Article 4 (2) of the German Law holds that "[s]hould such a person be on remand or held in confinement pending a German hearing, or should they have been sentenced to a term of imprisonment for purposes of correction and protective detention, [ . . ] they may be temporarily committed to the custody of the Tribunal". Others domestic legislations lay down this transfer of the detained witness but make it depend on the individual's assent. In this regard, the Swedish Act - in its Article 12 - contemplates that "[f]ollowing a decision by the Government, a person in Sweden who is deprived of his/her liberty may be transferred to the Tribunal for questioning or confrontation in connection with the preliminary investigation or in connection with a trial, if the questioning or confrontation refers to matters other than the crimes of the person deprived of liberty. Transfer may only take place if the person deprived of liberty has consented to the measure". However, the requirement of the subpoenaed witness' consent runs counter to the international obligation to transfer a detained witness to the ICTY. The Swedish Act does not abide by Rules 90 bis and 56 of the RPE, but, according to the principle of international law whereby a State cannot take advantage of its domestic legislation to vindicate non-compliance with its international duties, the

\footnotetext{
146 This is also provided by Rule 56 of the ICTR Rules. On the other hand, the Statute and the RPE of the ICC give this obligation a narrower scope: if the States still have to transfer the detained witness so that he can appear before the Tribunal, this transfer requires the witness' consent (Article 93 (7) of the Statute and Rule 192 of the RPE).
} 
Tribunal is allowed to ignore such implementing legislation which is contrary to its Rules.

Nevertheless, what happens when the reluctant witness remains unapprehended and at large? Neither the Statute nor the RPE expressly contemplate this assumption, which is not only surprising, but also unfortunate, as States seem to have no obligation to force such witnesses to appear.

However, on the one hand, this duty to transfer the free, but reluctant witness, can be derived from their general obligation to cooperate: paragraph 4 of Resolution 827 (1993) and Article 29 of the Statute of the Tribunal request States to comply with the Tribunal orders. Therefore, in case of a free, but reluctant witness, the Trial Chamber may issue a binding order and request the cooperation of the State of residence which, therefore, would be obliged to transfer the subpoenaed witness.

On the other hand, the power of national authorities to force a witness to comply with his subpoena can be inferred from their domestic laws; however, only three States have provided for this eventuality: the Netherlands, Germany, and the United Kingdom. Article 6 of the Dutch Act holds that the "[p]ersons in the Netherlands whom the Tribunal orders to be brought before it as witnesses [. . .] may be detained by order of the Public Prosecutor in The Hague and placed at the disposal of the Tribunal". Under Article 4 (2), the German Law also provides that "[s]hould the Tribunal require the personal appearance of a person at liberty within the area where this Law is in effect as a witness for the purposes of cross examination, confrontation or investigation, the same legal means may be employed to ensure their appearance as would be permissible in the case of a summons to appear before a German court or a German public prosecutor". ${ }^{147}$ According to both provisions, the reluctant witnesses are likely to be compelled to appear before the Tribunal by their national State. Finally, under Article 19 of the Order of 1996, the British authorities have the duty to participate in the compliance of a witness with a summons. And, what applies to a summons should apply, mutatis mutandis, to the subpoena, whose binding nature makes compliance therewith even more necessary. This obligation to transfer reluctant subpoenaed witnesses is strengthened by Article 9 of the Order, which entitles national courts to seize and transfer the reluctant witness upon request by the Tribunal.

\footnotetext{
${ }^{147}$ However, a note dated the October 13-14th, 1993 and written by the German delegation before the European Committee on Crime Problems indicated that "according to the state of present knowledge, the Statute does not demand compulsory surrender of witnesses or experts who are in Germany but not in detention", quoted in Klip (A.), supra [note 81], note 23, at 273.
} 
However, even though the free witness is forced to appear, he can still refuse to cooperate and not give evidence. ${ }^{148}$ If the need arises, the Trial Chamber may hold him in contempt of the Tribunal.

Eventually, the transfer of a subpoenaed individual depends on the witness' situation while the subpoena is issued. If he is detained on a State territory, the State will have to transfer him to the Tribunal pursuant to Rules 90bis and 56. On the contrary, if he is free, his transfer may proceed either from compliance with a formal request from the Tribunal, or from the implementing legislation of the State concerned. Nevertheless, one may underline that this transfer may also be spontaneous, as it was for the belligerent States, since BosniaHerzegovina, the Republic of Yugoslavia, and Macedonia transferred witnesses to the ICTY, whereas their own domestic laws do not make provision for it. ${ }^{149}$

\section{Sanction of the reluctant witness by his State of residence}

The reluctant witness is likely to be punished by the Tribunal pursuant to Rule 77 , but he also may be subjected to penalties by his national State. There is no doubt that "the assistance of national courts will be necessary when witnesses are unwilling to testify and deposition subpoenas are required to secure testimony. To that end, some [ . . .] legislation also provides that testimony may be compelled". ${ }^{150}$ Indeed, some domestic implementing legislation expressly contemplates punishment which includes not only the levy of a fine but may also include a prison sentence. This range of penalties used by the State to punish the reluctant witness appears, for example, at Article 8 of the Finnish Law, which states that "[a] witness summoned by the Tribunal [. . .] who fails to appear before the Tribunal without good excuse, [. . . ] refuses to give oath or solemn declaration or refuses to act as witness or to answer questions, shall have a fine imposed on him and, where necessary, under penalty of fine or sentence, shall be ordered to fulfil his duties as provided for in sections 36 and 37 of Section 17 of the Code of Procedure". This provision is unique because no other implementing legislation is as accurate and comprehensive. Most only

148 ICTY Trial Chamber, Order of transfer to the requested State, Prosecutor/Krsmanovic, IT-96-19 Misc. 1, quoted in Warbrick (C.), « Co-operation With the International Criminal Tribunal for Yugoslavia », International and Comparative Law Quarterly, vol. 45, October 1996, part. 4 , at 952 .

${ }_{149}$ Amnesty international On-Line, International Criminal Tribunals: Handbook for Governments Cooperation, supra [note 144].

${ }_{150}$ O'Shea (S.), «Interaction Between International Criminal Tribunals and National Legal Systems », Journal of International Law and Politics, vol. 28, Fall 1995 - Winter 1996, n 1-2, at 400 . 
provide that the State is entitled to compel the witness and, if necessary, to impose domestic penalties on him. To this effect, Article 7 (1) of the Spanish Act holds that the "[p]ersons summoned to appear before the International Tribunal as witnesses or experts shall be under the same obligation to appear as that provided for in Spanish law". Likewise, Italy contemplates the possibility of compulsory escort of the witness to an appearance the Tribunal. Its implementing legislation states, in its Article 10 (7), that "[w]hen the International Tribunal so requests, a witness [. . .] who has failed to appear [. . .] shall be coercively accompanied before it". Although these latest laws are lacking inaccuracy as for the applicable sanctions, they are useful for the ICTY: they correspond perfectly with the binding nature of the subpoena, and they efficiently complete the power of the Tribunal to hold the reluctant witness in contempt of the Tribunal. Such national provisions ensure the compliance of the subpoena.

The effective compliance of the subpoena ad testificandum and subpoena duces tecum relies upon the witness' State of residence. Although the only international duty of the State is to transfer the detained witness, domestic implementing laws introduce other complementary obligations, such as financial support, the transfer of the subpoenaed individual, and national sanctions for the reluctant witness. Nevertheless, as the domestic legislations are not wholly uniform, only some States have committed themselves to help the Tribunal in ensuring compliance with the subpoena, and through different methods.

\section{The limitation of the compliance of the subpoena by States}

As compliance with the subpoena depends on the cooperation of the State concerned, they are able to paralyse the enforcement thereof.

If the State decides to hinder the compliance of the subpoena, does the ICTY have the power to force it to cooperate? The ICTY was created by resolution 827 (1993) under Chapter VII so as to bind States to that resolution and the Statute attached thereto. However, if these international instruments demand that the State should cooperate for the production of evidence, they do not expressly provide for their assistance for compliance with the subpoena (except for the transfer of the detained witness included in the RPE). Moreover, the Tribunal is only vested with the power to issue binding orders to States which fail to cooperate; it cannot force them to, or impose penalties on them when they refuse to help the international Judge to compel the witness to comply with the subpoena. Nevertheless, the ICTY does possess procedural mechanisms that enable it to circumvent State reluctance. Its powers may be used 
either when the State prevents the witness from appearing before the ICTY (A) or when the State tries to limit the tenor of that testimony so as not to jeopardise its national security concerns (B).

A. The individual's inability to appear before the Tribunal because of the State

To prevent a witness from appearing or from producing documents before the Tribunal is detrimental to the Judges' mission. Thus, the Trial Chamber, in the Bla $k$ kić case, insisted on the fact that "the International Tribunal [has the] obligation to ensure a fair and expeditious trial and to afford the accused rights guaranteed by the Statute, for which access to evidence is a sine qua non". ${ }^{151}$ In order to avoid the possibility that State opposition paralyse compliance with the subpoena, the ad hoc Tribunal resorts to on-site investigations during which the ICTY agents travel to the witness' State of residence to collect evidence. Some authors call this mechanism a "passive form of judicial assistance" 152 since the on-site investigation is not conducted by the State - unlike the letters rogatory - but directly by the ICTY. ${ }^{153}$ Therefore, these on-site investigations are quite useful when the "States are either unable or unwilling to provide necessary legal assistance in the form required by the Ad Hoc Tribunals". ${ }^{154}$

Their legal basis may be found in Article 18 (2) of the Statute ${ }^{155}$ and Rule 39 (i) of the RPE, ${ }^{156}$ which entitle the Prosecutor to conduct pre-trial investigations

${ }^{151}$ ICTY Trial Chamber II, 18 July 1997, Decision on the Objection of the Republic of Croatia to the Issuance of Subpoena Duces Tecum, Prosecutor/Tihomir Bla· kić, IT-95-14-PT, para. 133.

${ }^{152} O$ 'Shea (S.), supra [note 150], at 398. This form of assistance "permits foreign officials or individuals to perform acts in one country which have legal effect elsewhere", Gori-Montanelli (R.) and Botwinik (D. A.), «International Judicial Assistance - Italy », International Law, ${ }^{\circ} 9$, 1975 , at 717.

153 These proceedings exist before the other international criminal courts. Rule 39 (i) of the RPE of the ICTR and Article 54 (2) of the Rome Statute also enable the Prosecutor to conduct on-site investigations. This is an essential tool for since the efficiency of the mission of these international criminal courts relies upon evidence situated in the forum delicti commissi.

${ }_{154}$ Sluiter (G.), «Obtaining evidence for the International Criminal Tribunal for the Former Yugoslavia: an overview and assessment of domestic implementing legislation », Netherlands International Law Review, XLV, 1998, at 107.

155 This provision stipulates that: "The Prosecutor shall have the power to question suspects, victims and witnesses, to collect evidence and to conduct on-site investigations. In carrying out these tasks, the Prosecutor may, as appropriate, seek the assistance of the State authorities concerned".

156 This Rule provides that "In the conduct of an investigation, the Prosecutor may: (i) summon and question suspects, victims and witnesses and record their statements, collect evidence and conduct on-site investigations" 
within the State territory. Such a power is rather original. Traditionally, international law forbids a State to exercise its jurisdiction within the territory of another State ${ }^{157}$ without the latter's consent, or at a minimum, its acquiescence. However, the ICTY has a vertical relationship with States, therefore suggesting that these on-site investigations should not create the same problems with the Tribunal as would be created in traditional inter-State relations. ${ }^{158}$ The lawful source of the authority to conduct on-site investigations should persuade States to allow the Tribunal to enjoy free access to their territory so that it conduct the investigations.

Nevertheless, some domestic legislation does not provide for this power. On the one hand, Austria and Finland allow these on-site investigations. Article 9 of the Austrian Federal Law states that "[t]he International Tribunal shall have the authority to hear independently witnesses and accused persons in Austria and to inspect localities and take other evidence, provided that the Federal Ministry of Foreign Affairs had been advised in advance of the time and subject of such investigations and that no measures of constraint have been taken or threatened by the International Tribunal during the conduct of the investigations". Likewise, the Finnish Law, under Article 7, accepts that "[t]he Tribunal may, in the territory of Finland, hear [. . . witnesses and victims of crime, carry out investigations". These two provisions are of particular relevance, since if the national authorities refuse to allow the subpoenaed witness leaves the country, the Judges of the ICTY could come to the reluctant State to question the witness.

On the other hand, some domestic legislation provides for the same power but subject it to the consent of the State. Article 7 of the Croatian Constitutional Act holds that " $[\mathrm{t}] \mathrm{he}$ Tribunal and the Prosecutor may, with the approval of the Government of the Republic of Croatia, undertake specific actions on the territory of the Republic of Croatia in order to investigate the crimes under its jurisdiction, except the actions which require force or encroach upon the fundamental rights and freedoms of citizens". As well, under Article 22, the Federal Order of Switzerland states that "the Federal Department of Justice and Police may authorise the prosecutor of the international tribunal concerned, should he so request, to carry out investigations on Swiss territory". Lastly, Article 4 (4) of the German Law provides that "[u]pon special request, with the consent of the competent German authorities, members and authorised officials of the Tribunal may independently conduct cross-examinations and investi-

${ }^{157}$ PCIJ, Judgement of September 7th, 1927, Lotus (France/Turkey), Series A, $n^{\circ} 10$, at 18.

${ }^{158}$ Besides, Article 9 (2) of the Guidelines holds that the national implementing legislation "should also provide that the Prosecutor and defence counsel may interview witnesses and experts in the territory after notice to the competent state authorities", supra [note 141]. 
gations and secure evidence by other similar means within the area where this Law is in effect. However, in these cases, also, the initiation and execution of coercive measures shall remain the preserve of the competent German authorities and shall conform to German law". According to these three provisions, the jurisdiction of the Tribunal, which depends on State assent, becomes ineffective. The State is in fine responsible for compliance with the order issued by international criminal Judges. However, if its State of residence prevents the subpoenaed witness to appear before the IT, it would hardly accept that the ICTY comes to its territory to cross-examine the individual.

Thus, if the ICTY possesses the means to thwart the unwilling State, the power to conduct on-site investigations is restricted by the substance of the domestic laws in effect. However, the Tribunal is still entitled to make a judicial finding and to report to the Security Council the State's failure to comply with its duty to cooperate, thus perhaps leading to international consequences. One must be mindful, again, that the ad hoc Tribunal is not vested with any enforcement power vis-à-vis States and the intervention of the Security Council in obtaining results is not guaranteed. Therefore, the proceedings before the ICC seem much more efficient: the on-site investigations can take place without State consent "if, whenever possible having regard to the views of the State concerned, the Pre-Trial Chamber has determined in that case that the State is clearly unable to execute a request for cooperation due to the unavailability of any authority or any component of its judicial system competent to execute the request for cooperation under Part 9" ${ }^{159}$ Without such a mechanism, the ICTY relies on the willingness of States.

B. The limits related to protection of the national security concerns of the official's State of dispatch

The State is likely to be opposed to the testimony for the reason that it might involve its national security concerns. Thus, one finds particular State reluctance to assist the ICTY in obtaining compliance with a subpoena when the witness is a soldier.

Usually, in domestic law, the testimony of the State agent depends on the permission of his superior who can refuse permission for his subordinate testifies owing to national security concerns. However, before the ICTY, even the States cannot withhold documents and refuse to comply with a binding order for national security concerns. Indeed, the Trial Chamber is vested with the power to modify the proceedings so that they not be prejudicial to that

159 Article 57 (3) (d) of the ICC Statute. 
State's interests. ${ }^{160}$ Therefore, the ICTY can ensures compliance with the binding order whilst taking into account the State's concerns about its security.

When the Tribunal issues a subpoena to a State official, he may hold information related to national security concerns. Does the procedures applicable to the binding orders apply to State officials acting in their private capacity? This question is all the more sensitive, given that the ICTY can issue a subpoena directly to the witness.

Most of the States are not reluctant to allow for the appearance of their soldiers who participated in the peacekeeping: for example, both BosniaHerzegovina $^{161}$ and the United Kingdom ${ }^{162}$ allowed their agents to appear before the ICTY when summoned. On the contrary, France resisted the subpoena issued to its soldiers considering there is no reason why a French commander-in-chief of a peacekeeping force should then be the only person responsible for the international mission. ${ }^{163}$ The French authorities considered that written testimony was the only possible solution. This reluctance was typical of the position of certain States, which consider that their soldiers who were peacekeepers still belong to the French army and do not become international agents, despite the Tribunal's position as outlined in the Bla·kić decision. However, if its national State prevents the soldier to appear, the witness

\footnotetext{
160 Through a balance of interests, the Trial Chamber may determine "whether, in view of a prima facie showing of a specified national security interest, a review of the relevant evidence is still required and, pursuant to such review, whether the specified national security interest of the State in non-disclosure of the relevant evidence outweighs the international public interest expressed by the SC in ensuring the effective administration of justice by the ICTY", Prosecutor's brief in support of subpoena duces tecum, Procureur/Tihomir Bla·kić, $1^{\mathrm{er}}$ avril 1997, aff. IT-95-14-PT, p. 33. In the Bla·kić case, the Appeals Chamber suggested practical methods and procedures so as to reconcile "the authority of the International Tribunal to order and obtain from States all documents directly relevant to trial proceedings, and the legitimate demands of States concerning national security", Appeals Chamber of the ICTY, 29 October 29th, 1997, Judgment on the Request of the Republic of Croatia for Review of the Decision of Trial Chamber II of 18 July 1997, Prosecutor/ Tihomir Bla·kić, IT-95-14-AR108bis, para. $67-68$.

${ }^{161}$ The Bosnian authorities did not prevent their generals from appearing before the ICTY. See the decision of the ICTY Trial Chamber of March 25th, 1999 in the Bla kic case.

${ }_{162}$ The United Kingdom did not prevent the appearance of Colonel Robert Stewart, former commander of the British battalion of the UNPROFOR. ICTY Trial Chamber, March 25th, 1999, Décision aux fins de comparution du Colonel Robert Stewart, Prosecutor/Tihomir Bla·kić, IT-95-14-T.

${ }_{163}$ Alain Richard (then French Defence Minister), Le Monde, December 5th, 1997, at 5 (our translation of: "il n'est pas envisageable que des chefs militaires français ayant assuré des commandements au sein d'une force internationale assument ensuite seuls la responsabilité d'opérations internationales").
} 
will find himself in an delicate situation: on the one hand, if he appears before the Tribunal, he breaches his duty to preserve secrecy; on the other hand, if he abides by the national rules, he does not comply with the subpoena and can be held in contempt of the Tribunal. ${ }^{164}$ The ICTY's position as an international institution found that international norms prevailed, and considered that even if the testimony jeopardises national security concerns, the State, bound by Article 29 of the Statute, cannot oppose its nationals' testimony. ${ }^{165}$ Therefore, French soldiers were compelled to appear, in particular, General Morillon. Nevertheless, as for the binding orders, the Tribunal modified the proceedings. The Trial Chamber refused to allow for that States limit the testimony of their soldiers: "[t]he limits to such cooperation [of States for the search of evidence] be established unilaterally under conditions other that those set down by the Judges within the context of the Statute and the Rules". ${ }^{166}$ However, it accepts that "a State could, exceptionally, refuse to disclose documents which might prejudice the interests of its national security provided, in particular: 1) that it is acting in good faith; and 2) that it proves to a Judge of the Trial Chamber designated to that end that the said documents put its security at risk and have no real importance for the case; that, in the case in point, and except for those documents which the Witness might consider appropriate to provide, the Trial Chamber does not request that others be disclosed". ${ }^{167}$ Therefore, the witness could profit by an in camera hearing and could point out to the Judges that the information is confidential. In this case, the Judges may not be able to force him to withhold the evidence.

Eventually, since the first Bla kić decision of the ICTY Trial Chamber II, the proceedings of the subpoena issued to individuals has been elaborated, although shortcomings remain. Whereas the Tribunal has powers of sanction and enforcement vis-à-vis witnesses, it still depends upon State cooperation. Thank to a progressive and constructive case-law, the ad hoc Tribunal is empowered to issue subpoenas to a broad category of private persons, i.e. the individuals acting in their private capacity which enables it to subpoena certain State officials. Since the individuals may be the addressees of an international order and since their responsibility may be entailed in case of noncompliance of the subpoena, they appear qua subjects of international law. Yet,

\footnotetext{
${ }^{164}$ Such a situation is related to the ELSI case: "What is a breach of treaty may be lawful in the municipal law and what is unlawful in the municipal law may be wholly innocent of violation of a treaty provision", ICJ, Judgement of July 20th, 1989, Elettronica Sicula (United States/Italy), Rep. 1989, at 51.

${ }^{165}$ ICTY Trial Chamber, May 12th, 1999, Decision on protective Measures for General Philippe Morillon, witness of the Trial Chamber, Prosecutor/Tihomir Bla·kić, IT-95-14-T.

166 Ibid., at 3.

167 Ibid., at 4.
} 
this is not full international personality since, with a few exceptions, both the service and the enforcement of the subpoena rely upon the State, which upholds the dominant role of the primary subjects of international law. Therefore, the witness is a subordinate subject within the probationary system of the ICTY since he may be the addressee of an international compulsory order whilst remaining under the tutelage of the State for its compliance.

Some jurists wished that "the development of the international criminal law of evidence that occurs through the work and precedent of the ICTY and ICTR will be one of the main contributions that the Tribunals can deliver to any future permanent international criminal Tribunal". ${ }^{168}$ Yet, this hope to see the improvements in the international criminal procedures applied to the ICC should not blind one to the consensual creation wherein the Court remains rooted. Indeed, the States which participated in the draft of the Rome Statute indicated their intention to control the functioning of the ICC. In consequence, there are some limits to the ICC power to subpoena individuals. Firstly, the concept of 'subpoena' does appear neither in the ICC Statute nor in its Rules; secondly, the Court depends on the State cooperation for the appearance of a witness. ${ }^{169}$ In addition, as Annalisa Ciampi points out, "[w]hile States Parties intended to establish a court with the power to investigate and prosecute persons allegedly responsible for crimes within its jurisdiction, this was only to the extent, and under the conditions, provided for in the Statute. The Statute does not necessarily purport to maximize the powers of the Court, and the corresponding States Parties' obligations". ${ }^{170}$ Therefore, the ICC will have to be cautious when asserting inherent power that is not expressly provided for in its Statute or RPE, especially a power of sanction and enforcement such as the subpoena. However, it is worth noting a progress with Article 72 of the Rome Statute which condones an aspect of the Blarkic judgement: if necessary, there could be special procedures when national security concerns are at stake, but these interests will not exempt the State official from assisting the Court. Such a balance between the protection of the interests of the witness and of international criminal justice are proper to ensuring the efficiency of the International Criminal Court.

168 Dixon (R.), « Developing International Rules of Evidence for the Yugoslav and Rwanda Tribunals », Transnational Law and Contemporary Problems, vol. 7, 1997, at 102.

169 Article 93 of the ICC Statute.

${ }_{170}$ Ciampi (A.), «The Obligation to Cooperate ", in Cassese (A.), Gaeta (P.) and Jones (J.R.W.D.), The Rome Statute of the International Criminal Court: A Commentary, Oxford University Press, 2002, vol. II, at 1615. 


\section{Organisations and their agents}

A great many international entities were present in the territory of the former Yugoslavia. They intervened either for peacekeeping operations or for monitoring functions or for humanitarian action. Thus, four peacekeeping missions - UNPROFOR, IFOR, SFOR and KFOR - and some international entities OSCE, UEMM, ICRC, MSF - play a crucial role in the production of evidence. Indeed, due to their field presence, these international organisations and their agents may "have first hand information of potentially high importance for the Tribunal's work". ${ }^{171}$

Within the international criminal proceedings and pursuant to Rule 54 of its RPE, the ICTY is endowed a specific power that enables it to issue binding orders to States and subpoenas to individuals. Through its case-law, the International Tribunal has erected a peculiar mechanism ${ }^{172}$ that may be divided into two main lines: firstly, although States are bound to cooperate with the Tribunal for the production of documents, their sovereignty and their international status prevent them from being compelled to produce evidence. Hence, Judges are only empowered to issue them binding orders and are not entitled to impose penalties upon them. Such a restriction is justified by the close dependence of the international criminal proceedings vis-à-vis international law which still governs most of its aspects. ${ }^{173}$ Secondly, with regard to individuals, the Tribunal issued an expansive interpretation of the term "acting in a private capacity" under which State officials shall be treated as private individuals. Such an approach enables the ICTY to subpoena witnesses, being private persons or public agents, and to hold them in contempt of the Tribunal in cases of non-compliance. ${ }^{174}$

The relationship between the Tribunal, on the one hand, and the international organisations and their agents, on the other, maintains the same dichotomy. On the first hand, although some of its early case-law appeared to deny that the Judges' power to issue binding orders to international entities existed, the Tribunal finally considered that it was empowered to issue such binding orders

${ }^{171}$ Bank (R.), supra [note 31], at. 256.

172 See Appeals Chamber of the ICTY, October 29th, 1997, Judgement on the Request of the Republic of Croatia for Review of the Decision of Trial Chamber II of 18 July 1997, Prosecutor/ Tihomir Bla·kić, IT-95-14-AR108bis.

173 Ascencio (H.), L'autorité de chose décidée en droit international public, Thèse soutenue le 4 décembre 1997, Paris X-Nanterre, at 87 (our translation of: "l'étroite dépendance [of the international criminal proceedings vis-à-vis] du droit international général qui continue à en régir la plupart des manifestations").

${ }_{174}$ See supra-Individuals-. 
to international entities (Part I). On the other hand, if the ICTY recognised its power to issue subpoenas to the peacekeepers, this power does not extend to all international agents (Part II).

Part I. The ICTY's power to issue binding orders to international organisations

International organisations and peacekeeping operations participated in the restoration of international peace and security in the Balkans. Their unique role in that has inevitably led to them coming into possession of documents susceptible to be used in judgement proceedings before the ICTY. Therefore, one must consider whether the Tribunal is vested with the power to issue subpoenas to international organisations.

One may contemplate the following syllogism: as the ICTY has jurisdiction to issue binding orders to States (major), and as international organisations consist of States (minor), the ICTY is vested with the power to issue binding orders to international organisations. ${ }^{175}$ Nevertheless, such reasoning remains to be confirmed in the case-law of the Tribunal. Thus, both the relationship between the Tribunal and the UN constituent organs (Section I), and between the Tribunal and international organisations not formally a part of the United Nations system (Section II), must be examined.

\section{Section I. The ICTY power vis-à-vis the constituent organs of the United Nations}

Owing to the special link that unites the Tribunal and the United Nations especially the Security Council - the Judges have recognised their power to address binding orders to the UN entities. Such an analysis implies a distinction between UN organs proper (I) and UN organisations (II).

\section{The relations between the Tribunal and the UN organs}

The ICTY stems from a Security Council resolution adopted under Chapter VII - resolution 827 (1993) - and it is one of its subsidiary organs. Therefore,

\footnotetext{
${ }^{175}$ On the one hand, Rule 36 of the ICTY RPE enables the Prosecutor to request the assistance of international entities, but this provision neither creates a duty to cooperate for the international organisations nor entitles the Judges of the Tribunal to issue subpoenas to them. On the other hand, such a syllogism is useless for the ICC since Article 87 (6) of its Statute provides that the international organisations should collaborate with the Court which "may ask [them] to provide information or documents".
} 
the relationship between the ICTY and UN organs should be similar to the relationship between the Security Council and other UN organs. In the framework of the maintenance of international peace and security, all Member States and UN organs are bound by the decisions of the Council, who was granted primary responsibility therefore under Article 24 of the Charter. As Security Council decisions under Chapter VII are binding on all States and UN organs, UN organs should also be required to cooperate with the Tribunal for the production of evidence. It is to be noted, however, that the ICTY came to an equivocal decision in the Prijedor case: ${ }^{176}$ while the Trial Chamber did not expressly decline its power to issue binding orders to the UN Secretariat, it refused to deliver it. Despite this ambiguity, two points allow one to assert that it is not a refusal in principle.

On the one hand, the motivations behind that rejection are formal. The Judges considered that the request of the Defence did not comply with the requirements laid down by the Bla kić Judgement in 1997. ${ }^{177}$ No substantial motive (as the quality of being a UN organ) could over-ride the refusal to issue the order. Therefore, when the requirements are satisfied, the ICTY may be empowered to issue a binding order to the General Secretariat.

On the other hand, the enacting terms of the decision speak for themselves because the Judges implicitly assume the possibility to issue a binding order to the General Secretariat of the Organisation. The ICTY "declines to consider issuing a binding order at this stage of the proceedings and notes as follows:

1) If the Defence wishes to pursue the matter, Defence counsel should first approach the United Nations Secretariat and request the material from it, providing sufficient information to the Organization to permit it to identify and locate the items sought; and 2) If the material is not forthcoming, the Defence may raise the matter again before the Trial Chamber, providing full details of the items sought, their relevance to the matter before the Trial Chamber and their known or presumed location, together with written confirmation of the views of the United Nations Secretariat as to their production". ${ }^{178}$ Therefore, the Tribunal leaves the possibility open while suggesting certain requirements likely to ensure the admissibility of such a request. Hence, the Tribunal is empowered to issue binding orders to UN organs.

${ }^{176}$ ICTY Trial Chamber, July 1st, 1998, Decision on Defence Motion to Issue Subpoena to United Nations Secretariat, Prosecutor/Milan Kovaœević, IT-97-24-T.

177 Especially the criteria of specificity, relevance of the documents sought, and the relative ease of execution. All the requirements to issue a binding order are now listed in Article 54bis of the RPE.

178 ICTY Trial Chamber, July 1st, 1998, Decision on Defence Motion to Issue Subpoena to United Nations Secretariat, Prosecutor/Milan Kovaœević, IT-97-24-T[emphasis added]. 


\section{The relations between the ICTY and the international organisations of the UN}

If it seems natural to extend the Kovacević case to international entities without an international legal personality separate from the UN (a), what happens for international organisations which belongs to the UN system but have a separate legal personality (b)?

(a) Peacekeeping operations may illustrate the first assumption because they do not have an autonomous legal personality. These operations are UN-led forces and a concrete demonstration of the concept of collective security. In the former Yugoslavia, the Security Council created successively four peacekeeping missions in pursuance of Chapter VII: UNPROFOR - resolution 743 (1992) - replaced by the IFOR - resolution 1031 (1995) - and by the SFOR resolution 1088 (1996) - whose action was eventually completed by the KFOR in the Kosovo - resolution 1244 (1999). One may wonder whether the power to issue a binding order to these forces relies upon the existence of a duty to cooperate, either for peacekeeping missions or for the participating States.

Resolution 1244 (1999) expressly enjoins KFOR to cooperate with the ICTY. ${ }^{179}$ Thus, the obligation to assist the Tribunal for the production of evidence affects directly the peacekeeping forces. As for the IFOR evolved into SFOR, its relationship with the Tribunal became more complicated: the constituent resolutions do not provide for direct cooperation between SFOR and the Tribunal, and put the operations under the command of the NATO. Indeed, Article 1 of the Dayton Agreement holds that "NATO may establish such a force, which will operate under the authority and subject to the direction and political control of the North Atlantic Council ("NAC") through the NATO chain of command" ${ }^{180}$ In the Simic case, the Trial Chamber considered that a binding order issued to the SFOR "should be as applicable to collective enterprises of States as it is to individual States; Article 29 should, therefore, be read as conferring on the International Tribunal a power to require an international organization or its competent organ such as SFOR to cooperate with it in the achievement of its fundamental objective of prosecuting persons responsible for serious violations of international humanitarian law, by providing the sev-

\footnotetext{
179 Under paragraph 14 of the resolution, the Security Council "[d]emands full cooperation by all concerned, including the international security presence, with the International Tribunal for the Former Yugoslavia”, resolution 1244 (1999), Security Council, June 10th, 1999 [UN Doc. S/Res/1244 (1999)], para. 14.

180 Article I (1) (b) of the Annex 1A of the General Framework Agreement for Peace, Agreement on the Military Aspects of the Peace Settlement.
} 
eral modes of assistance set out therein". ${ }^{181}$ In spite of the modal 'should', the Trial Chamber did deliver a binding order to the SFOR through the NATO Council and to each involved States. ${ }^{182}$ According to Judge Robinson, appending a separate opinion, the power to issue binding orders to peacekeeping operations follows from a "strong functional, although not organic" 183 link which exists between these international forces and the ICTY. Hence, the Tribunal should be vested with the power to issue binding orders to the entities responsible for the arrest of the accused under its jurisdiction to force them to produce the evidence related to these arrests.

(b) On the other hand, may the ICTY be able to issue binding orders to international organisations vested with independent legal personality but included within the UN system, such as UNESCO or the WHO? Such Specialised Agencies always conclude bilateral agreements with the UN, pursuant to Article 63 (1) of the Charter. ${ }^{184}$ Some provisions may compel them to provide "such assistance to the Security Council as the Council may request including assistance in carrying out decisions of the Security Council for the maintenance or restoration of international peace and security". ${ }^{185}$ As the creation of the ICTY arises from a resolution adopted under Chapter VII, these international organisations have the duty to cooperate with the Tribunal and to comply with its decisions, especially for the production of evidence. The ad hoc Tribunal is therefore empowered to issue binding orders to independent organisations of the UN system.

${ }^{181}$ ICTY Trial Chamber, October 18th, 2000, Decision on Motion for Judicial Assistance to be Provided by SFOR and Others, Prosecutor/Blagoje Simić, Milan Simić, Miroslav Tadić, Stevan Todorović, Simo Zarić, IT-95-9-PT, para. 48.

${ }^{182}$ It is worth specifying that, eventually, as the defendant entered a guilty plea, there was no need to make a request to SFOR to produce evidence. Consequently, the Appeals Chamber vacated the binding order, ICTY Appeals Chamber, March 27th, 2001, Order on Request for Review Pursuant to Rule 108bis of Decision on Motion for Judicial Assistance to be Provided by SFOR and Others Dated 18 October 2000, Prosecutor/Blagoje Simić, Milan Simić, Miroslav Tadić, Stevan Todorović, Simo Zarići, IT-95-9.

183 Separate Opinion of Judge Robinson, Decision on Motion for Judicial Assistance to be Provided by SFOR and Others, Prosecutor/Blagoje Simić, Milan Simić, Miroslav Tadić, Stevan Todorović, Simo Zarić, October 18th, 2000, IT-95-9-PT, para. 6.

184 Article 63 (1) of the UN Charter provides that: "[ $t]$ he Economic and Social Council may enter into agreements with any of the agencies referred to in Article 57, defining the terms on which the agency concerned shall be brought into relationship with the United Nations".

185 Vitzthum (W. G.), « On article 2 (6) », in Simma (B.) (ed.), The Charter of the United Nations, A Commentary, Oxford University Press, Oxford, 1994, para 17. 


\section{Section II. International organisations outside the UN system}

In principle, as the ancient maxim 'par in parem non habet imperium' establishes, the Tribunal could not issue orders to international organisations. In international law, there is no hierarchy between independent organisations; therefore, the ICTY is powerless facing entities out of the UN system.

Nevertheless, a relationship may be established between the ICTY and an independent international organisation when this is authorised to take action by the Security Council under Chapter 7 as it happened for NATO, ${ }^{186}$ which had been authorised to act through the IFOR/SFOR. Besides, if the Security Council supervises the peacekeeping operation, the link between the activity of the international organisation and the Tribunal becomes structural, such that subordination of the international organisation vis-à-vis the Tribunal may arise.

However, if the international organisation, although entitled to take action by the Security Council, supervises the mission, the ICTY cannot issue a binding order to it, as found by the Tribunal itself, regarding the OSCE, in the Kovaœević decision. ${ }^{187}$ Under paragraph 5 and Annex 2 of resolution 1244 (1999), this organisation acted under UN 'auspices' and not under its 'authority'. Indeed, the Security Council decided "on the deployment in Kosovo, under United Nations auspices, of international civil and security presences, with appropriate equipment and personnel as required, and welcomes the agreement of the Federal Republic of Yugoslavia to such presences". ${ }^{188}$ The ICTY inferred from this text that it cannot issue a binding order to the OSCE.

However, the legal basis of this decision is merely nonexistent; this makes the entire decision quite debatable and hazardous. ${ }^{189}$ Indeed, some authors pointed out that this judgement entitles member States of the OSCE to "s'abriter derrière les organisations qu'ils mettent en place". ${ }^{190}$ Although "an

\footnotetext{
${ }^{186}$ It is worth pointing out that when an applicant requests the issue of orders to the NATO, he requires both the NATO and its members States to produce documents, ICTY Trial Chamber, November 14th, 2003, Ex Parte Order staying Rule 54bis Proceedings, Prosecutor/Milan Milutinovic, Dragoljub Ojdanic, Nikola Sainovic, IT-99-37-PT.

${ }_{187}$ ICTY Trial Chamber, June 23rd, 1998, Decision Refusing Defence Motion for Subpoena, Prosecutor/Milan Kovacević, IT-97-24-T.

${ }^{188}$ Resolution 1244 (1999), supra [note 179], para. 5. See also its Annex 2 (3) which provides the "Deployment in Kosovo under United Nations auspices of effective international civil and security presences, acting as may be decided under Chapter VII of the Charter, capable of guaranteeing the achievement of common objectives".

${ }^{189}$ Ascencio (H.) et Maison (R.), «L'activité des tribunaux pénaux internationaux (1999) », Annuaire Français de Droit International, 1998, at 382.

190 Ibidem.
} 
organisation does not acquire necessarily the obligations of each of its members"; ${ }^{191}$ the duty to cooperate under Article 29 of the Statute and under resolution 827 (1993) "appl[y] to all States, whether acting individually or collectively". ${ }^{192}$ In consequence, member States of an international organisation outside the UN system have the obligation to assist the Tribunal for the production of evidence. This duty to cooperate, which does not bind the international organisation, breaks through the judicial veil of the organisation and directly reaches the member States, which should comply with their obligations within the framework of their organisation.

The Tribunal subsequently went beyond this reasoning and implicitly recognised an obligation to cooperate which is directly part of the duty of the independent international organisation. The order issued by the Trial Chamber in the Kordic et Eerkez ${ }^{193}$ ended complex proceedings. The EUMM was the subject of the case at hand, as the ICTY had tried to gain evidence from it. The Judges first issued a binding order directly to the EUMM, and then to its organs concerned, i.e. the Presidency of the Council of the European Union and the European Commission. This decision of May 3rd, 2000 being unavailing, the Trial Chamber issued, on August 4th, 2000, a new order to the whole of the member States of the European Community at the time of the creation of the EUMM. Such a solution may be surprising because the Tribunal applies to the organisation's organs and to its member States. However, traditionally, an international organisation is defined as an "organization established by a treaty or other instrument governed by international law and possessing its own international legal personality". ${ }^{194}$ Therefore, all the international organisations are independent and their acts entail the organisation itself, but not their member States. ${ }^{195}$ The ICTY should have restricted itself to issuing a binding order

191 Figa-Talamanca (N.), « The role of NATO in the Peace Agreement for Bosnia and Herzegovina », European Journal of International Law, vol. 7, 1996-II, at 173.

${ }^{192}$ ICTY Trial Chamber, October 18th, 2000, Decision on Motion for Judicial Assistance to be Provided by SFOR and Others, Prosecutor/Blagoje Simić, Milan Simić, Miroslav Tadić, Stevan Todorović, Simo Zarić, IT-95-9-PT, para. 46.

${ }^{193}$ ICTY Trial Chamber, August 4th, 2000, Order for the Production of Documents by the European Community Monitoring Mission and its Member States, Prosecutor/Dario Kordić et Mario Eerkez, ex parte partly confidential, IT-95-14/2.

${ }^{194}$ Article 2 of the ILC Draft on the Responsibility of International Organizations, Report of the International Law Commission, 55th session, 5 May-6 June and 7 July-8 August 2003, at. 33 .

${ }^{195}$ This is the argument used by some member States of the NATO before the ECHR. In the Banković case, Yugoslav citizens instituted proceedings against States both members of the NATO and signatory countries of the ECHR. The applicants considered that the bombing of the headquarters of the Serbian radio and television constituted a breach of their freedom of expression. The question was to determine whether the governments of those States were 
to the EUMM organs. However, as emphasises Professor Klein, a direct responsibility (of member States) is not impossible if they were personally bound by the violated rule. ${ }^{196}$ Indeed, as the International Law Commission states, "the legal personality of an organization [. . . ] needs to be 'distinct from that of its member States" ". ${ }^{197}$ It adds that "the existence for the organization of a distinct legal personality does not excluded the possibility of a certain conduct being attributed both to the organization and to one or more of its members or to all of its members". ${ }^{198}$ However, the States are bound by their obligation to cooperate so that the ICTY is vested with the power to apply to both States and organisation. In the Kordic et Eerkez case, the ICTY actually admits its jurisdiction to issue a binding order directly to the international organisation out of the UN system, since the first order was delivered to the EUMM and its organs concerned. Furthermore, in spite of non-compliance with the decision of the 3 May 2000 and the issuance of another binding order to the member States, it is the organ in question of the EUMM - the Presidency of the Council of the EU - which brought the required documents before the Tribunal. In 2003, the ICTY again turned to the EUMM and requested that the Head of the mission provide the Defence with access to the full archives. The EUMM refused to meet the request because of "the risk of jeopardising the EUMM Mission and monitors in field and the possible misuse of EUMM material". ${ }^{199}$ The Trial Chamber declines to consider issuing a binding order at this point, because the requirements of Rule 54bis were not satisfied, i.e. "the material sought [has not] been identified or described by its general nature ['as clearly as possible even though it cannot describe them in detail'], and [. . . ] a

responsible for such an act committed by the NATO forces. According to the States involved, "le bombardement litigieux est imputable non aux Etats défendeurs mais à l'OTAN, organisation dotée d'une personnalité juridique internationale distincte de celle de ses Etats membres", ECHR., decision of December 19th, 2001, Banković and others/Belgium and sixteen other States, $\mathrm{n}^{\circ} 52207 / 99$, para. 32. Finally, the Court did not answer the motion since the claim was declared inadmissible.

${ }^{196}$ Klein (P.), La responsabilité des organisations internationales dans les ordres juridiques internes et en droit des gens, Bruylant, Bruxelles, 1998, at. 431: "une responsabilité directe des Etats membres [. . .] n'est toutefois pas entièrement exclue pour autant mais, [. . . ] elle doit alors être fondée sur un fait spécifique montrant que les Etats membres sont [. . . ] personnellement tenus par la règle violée".

197 ILC draft on the Responsibility of International Organizations, Report of the International Law Commission, 55th session, 5 May-6 June and 7 July-8 August 2003, at 43, quoting Sir Fitzmaurice (G.), in A/CN. 4/101, Article 3, Yearbook of the ILC, 1956-II, at 106.

${ }^{198}$ ILC draft on the Responsibility of International Organizations, Ibid.

199 ICTY Trial Chamber II, September 12th, 2003, Decision on Defence Access to EUMM Archives, Prosecutor/Enver Hadzihasanovic, Amir Kubura, IT-01-47-PT. 
legitimate forensic purpose for such access [has not been] shown". ${ }^{200}$ Consequently, the ICTY recognises that a binding order may be issued to the EUMM, provided that the request meets the requirements of Rule 54bis. Nevertheless, in December 2003, the Tribunal laid down another condition: although it recognized that the motion met the requirements set out in Rule 54bis, it considered that it would be appropriate to follow the same procedure agreed upon in relation to the Defence access to UNPROFOR material, i.e. "the Defence was granted access to the relevant archives, and 'selected relevant documents from the archives which were then vetted by the United Nations, and where necessary, redacted to ensure that the interests of the Organisation and its member States would not be compromised". ${ }^{201}$ Eventually, all these standards appear to be able of meeting the interests of the applicant and of the entity providing access to its archive, especially in case of confidential concerns of the entity. ${ }^{202}$

Therefore, the Tribunal is empowered to issue binding orders not only to UN organs and entities but also to organisations outside the UN system. Hence, the ICTY can collect relevant evidence from most of the entities having participated in settlement of the Balkan crisis.

It is worth adding that in case of non-compliance, the Tribunal may be entitled to make a judicial finding to that effect and report it to the Security Council. ${ }^{203}$ The Security Council might then take measures, either against the UN organs involved, or against the member States of these delinquent international organisations. ${ }^{204}$ One must concede that the proceedings are not under the control of the ICTY since it is not vested with any enforcement or sanctioning power against intergovernmental organisations and their member States. Such a situation is a revelatory sign of State influence within the international criminal legal order. However, whereas the Tribunal power is so limited vis-à-vis international organisations, it seems more efficient vis-à-vis the employees of these organisations.

${ }^{200}$ Ibidem.

${ }^{201}$ ICTY Trial Chamber II, December 15th, 2003, Decision on Defence Motion for Access to EUMM Archives, Prosecutor/Enver Hadzihasanovic, Amir Kubura, IT-01-47-T.

${ }^{202}$ Ibidem.

${ }^{203}$ Proceedings used for the State non-compliance with a binding order. See ICTY Appeals Chamber, October 29th, 1997, Judgement on the Request of the Republic of Croatia for Review of the Decision of Trial Chamber II of 18 July 1997, Prosecutor/ Tihomir Bla·kić, IT-95-14AR108bis, para. 33-37.

${ }^{204}$ Since they are bound by paragraph 4 of resolution 827 (1993) and Article 29 of the ICTY Statute. 
Part II. The ICTY power to subpoena international agents

In 1997, the Appeals Chamber stated that the ICTY was vested with the power to issue subpoenas to individuals. ${ }^{205}$ The Judges gave a broad interpretation to the term "individuals acting in their private capacity", which includes State officials ${ }^{206}$ and international agents. Pursuant to Rule 54 of its RPE, the ad hoc Tribunal is therefore empowered to subpoena the employees of the international organisations (Section I). Nevertheless, the Judges admit that the mission of certain agents requires a specific treatment likely to exempt them from being compelled to testify (Section II).

\section{Section I. The subpoenaed agents of international organisation}

In addition to the State officials acting in their private capacity, the Appeals Chamber, in the Bla kić case, contemplates a fourth assumption which enables it to issue subpoenas to peacekeepers (I). The subsequent cases confirm this exemption and extend it to the staff of international organisations (II).

\section{The peacekeepers}

Binding orders may be issued to peacekeeping missions qua international organisations. ${ }^{207}$ One may wonder whether the ICTY is vested with the power to issue subpoenas to the soldiers of these operations.

According to the Appeals Chamber, the official of an international force should be regarded qua an individual acting in his private capacity. This inclusion of soldiers in the same category as individuals may, at first, seem inconsistent. How could the Judges justify their position? They state that the officials of a peacekeeping operation are members of "an international armed force [...] and not [. . .] of the military structure of [their] own country". ${ }^{208}$ While they participate in these missions, the soldiers lose their quality of official of the State army and acquire the quality of international agents. ${ }^{209}$ However, does

\footnotetext{
${ }^{205}$ See supra -Individuals-.

${ }^{206}$ Three assumptions identified in the Bla-kić case are related to State organs: the State agent, witness before entering its function; the State agent in office, casual witness of breaches of international humanitarian law committed by a superior in rank; the reluctant State official. All these hypothesis are dealt with in supra-Individuals-, Part I, Section I (II).

207 See supra -Organisations and their agents-, Part I, Section I (II) (a).

${ }^{208}$ ICTY Appeals Chamber, October 29th, 1997, Judgement on the Request of the Republic of Croatia for Review of the Decision of Trial Chamber II of 18 July 1997, Prosecutor/ Tihomir Bla-kić, IT-95-14-AR108bis, para. 50.

${ }_{209}$ According to the ICJ, this notion concerns "any person who, whether a paid official or not,
} 
the posting of the national armed forces under international command really render unimputable the military structures of the participating States? The Appeals Chamber considered that the ICTY and these operations stem from the Security Council and their mandate had a common substratum, a resolution of this UN organ. This argument which was reasonable for the direct relationship between the Tribunal and the international force is, however, not suitable for the soldiers of these forces. Indeed, the only reason which would vindicate the theory ofthe non-imputability to the national structures would be the fact that the soldier is an official of an international operation, and would be that the command of the peacekeeping mission belongs to the UN. It is therefore necessary to study the relationship between the UN and the States which supply the armed contingents.

On the one hand, States consider that ultimate command remains with their staff whilst the UN is entrusted with the operational control. In 1996, France pointed out that "il serait souhaitable de préciser la nature de l'autorité dont dispose le commandement de la force (et, au bout du compte, le Secrétaire général) sur les unités nationales. La France estime que cette autorité devrait se rapprocher du contrôle opérationnel". ${ }^{210}$ Likewise, the United States considers "the US policy is for transfer of only operational control, not command" 211 which remains with national structures.

On the second hand, one may examine whether the positive law governing the UNPROFOR, the IFOR/SFOR and the KFOR confirms that only operational control is assigned to the UN. ${ }^{212}$ If such is the case, the decision of the Appeals Chamber would be unfounded. Under paragraph 2 of resolution 743 (1992) creating the UNPROFOR, this peacekeeping operation is expressly

and whether permanently employed or not, has been charged by an organ of the Organization with carrying out or helping to carry out, one of its functions - in short, any person through whom it acts", Advisory Opinion of April 11th, 1949, Reparation for Injuries Suffered in the Service of the United Nations, Report 1949, at 177.

${ }^{210}$ Letter of the French permanent representative presented before the UN and addressed to the Secretary-General and dated January 18th, 1996, January 30th, 1996, [UN Doc. A/50/869].

211 «Le droit militaire et l'usage des forces armées dans un nouvel ordre mondial », Recueils de la société internationale de droit militaire et de droit de la guerre, 1994, vol. I, at 199.

${ }^{212}$ In 1969, with regard to the UN Peacekeeping Forces in Cyprus (UNFICYP), the House of Lords considered that the criterion on which to establish the effective control was the operational control. It stated that "though national contingents were under the authority of the United Nations and subject to the instructions of the commander, the troops as members of the force remained in their national service. The British Forces continued, therefore, to be soldiers of Her Majesty”, per Lord Morris, Attorney General v. Nissan, All England Law Reports 1, 1969, at 629, quoted by Bank (R.), « Cooperation with the International Criminal Tribunal for the Former Yugoslavia in the Production of Evidence », Max Planck Yearbook of United Nations Law, 2000, note 66, at 258. 
subjected to the authority of the Security Council while the "civilian and military heads of the mission were appointed by the United Nations". Therefore, the argumentation of the ICTY regarding the obliteration of national structures is defensible. On the contrary, IFOR and SFOR are composed of national forces entitled to act under a unified command by the Security Council. Under paragraph 14 of resolution 1031 (1995), the Security Council "[a]uthorizes the Member States acting through or in cooperation with the organization referred to in Annex 1-A of the Peace Agreement to establish a multinational implementation force (IFOR) under unified command and control in order to fulfil the role specified in Annex 1-A and Annex 2 of the Peace Agreement". Likewise, resolution 1088 (1996) creates the SFOR "as the legal successor to IFOR", placing it "under unified command and control". ${ }^{213}$ Yet, a unified command of national contingents does not square with an international army managed by the UN. This argument can be applied to KFOR whose action remains imputable to States and especially to NATO. Consequently, since the soldiers remain under the operational command of States, they should keep their quality of official of their sending State. The extension of the category of individuals acting in their private capacity to the peacekeepers does not seem relevant - except for the UNPROFOR. For this reason, one should underline that the ICTY only issued a subpoena ad testificandum to members of the UNPROFOR qua international agents. ${ }^{214}$

Nevertheless, supposing that these soldiers are effectively international agents as stated by the Appeals Chamber, they will enjoy immunities pursuant

\footnotetext{
${ }^{213}$ Paragraph 18 of resolution 1088 (1996), The situation in Bosnia and Herzegovina, Security Council, December 12th, 1996 [UN Doc. S/Res/ 1088 (1996)].

${ }^{214}$ See ICTY Trial Chamber, March 25th, 1999, Décision aux fins de comparution du Colonel Robert Stewart, Prosecutor/Tihomir Bla·kić, IT-95-14-T; and ICTY Trial Chamber, May 12th, 1999, Decision on protective Measures for General Philippe Morillon, witness of the Trial Chamber, Prosecutor/Tihomir Bla·kić, IT-95-14-T. It is true that a subpoena ad testificandum was addressed to Commanding General of SFOR, Mr Shinseki; yet, the Judges insisted that "he is not representing this State and is to be treated qua individual in respect of any event that he has personally witnessed, even if observed while performing his official functions. Thus he is compellable not in his role as Commanding General of SFOR but as an individual with personal knowledge of the events of which complaint is made. Similar considerations will apply to any other SFOR personnel who are shown to have direct knowledge of these events", ICTY Trial Chamber, October 18th, 2000, Decision on Motion for Judicial Assistance to be Provided by SFOR and Others, Prosecutor/Blagoje Simić, Milan Simić, Miroslav Tadić, Stevan Todorović, Simo Zarić, IT-95-9-PT, para. 62. This is worth noting that, as the defendant entered a guilty plea, this subpoena was cancelled by the Appeals Chamber on March 27th, 2001 in its Order on Request for Review Pursuant to Rule 108bis of Decision on Motion for Judicial Assistance to be Provided by SFOR and Others Dated 18 October 2000, Prosecutor/Blagoje Simić, Milan Simić, Miroslav Tadić, Stevan Todorović, Simo Zarići, IT-95-9.
} 
to the Convention on the Privileges and Immunities of the United Nations of 13 February 1946. ${ }^{215}$ The ICTY should ask the UN Secretary for the removal of this immunity. ${ }^{216}$ Such a request was initiated by the Tribunal to obtain the appearance of General Philippe Morillon. ${ }^{217}$

Therefore, the broad interpretation of "individuals acting in their private capacity" with regard to peacekeepers seems, firstly, restricted to members of UNPROFOR and, secondly, dependent on the removal of their immunity by the UN Secretary-General. On the other hand, although the Appeals Chamber does not contemplate the assumption in the Bla.kic case, it is worth wondering whether the ICTY is empowered to issue subpoenas to international agents lato senso.

\section{The agents of the international organisations}

Two hypotheses should be distinguished: when the individual, although working within the organisation, remains a representative of his sending State, and when he is an international agents acting on behalf of his organisation.

On the one hand, if the witness acts within the organisation as a representative of the State, he remains a State agent and does not acquire the quality of international agent. The ICTY should issue a binding order to the State concerned so that the witness may appear before it. This mechanism was used in 1999 by the Trial Chamber, in the Bla $\cdot k i c$ case, in order to ensure the appearance of Jean-Pierre Thébault, head of the EUMM. ${ }^{218}$ The EUMM was created

\footnotetext{
${ }^{215}$ Convention on the Privileges and Immunities of the United Nations, 1 U.N.T.S. 15, February 13th, 1946.

${ }^{216}$ The ICTR did so in 1998: in the framework of the Akayesu case, the Tribunal summoned a former commander-in-chief of the UNAMIR, General Roméo Dallaire. On January 14th, 1998, the UN Secretary-General, Koffi Annan, removed the Canadian General's immunity. See ICTR Trial Chamber I, November 19th, 1997, Décision faisant suite à une requête aux fins de délivrance d'une citation à témoin, Prosecutor/Jean-Paul Akayesu, ICTR-96-4-T.

${ }^{217}$ ICTY Trial Chamber, May 12th, 1999, Decision on protective Measures for General Philippe Morillon, witness of the Trial Chamber, Prosecutor/Tihomir Bla·kić, IT-95-14-T. However, since the soldiers might hold information related to national security concerns, the Tribunal admitted to fit the proceedings in order to "not to risk affecting the proper conduct of peace-keeping operations both from the point of view of the UN and, in particular, of its Secretary-General, and also from the point of view of the States contributing troops". The Trial Chamber should examine whether the evidence provided by the soldiers might not "create difficulities for the military and humanitarian action of the UN and France in that region". As for the details of the proceedings, see supra -Individuals-, Part II, Section II (II) (B).

${ }^{218}$ ICTY Trial Chamber, May 13th, 1999, Decision of on protective measures for Mr JeanPierre Thébault, witness of the Trial Chamber, Prosecutor/Tihomir Bla·kić, IT-95-14-T.
} 
by an intergovernmental agreement adopted by the member States of the European Community so that its head was only acting on behalf of the member States. He was a State official to whom a subpoena could not be issued. However, in the present case, another point should be underlined: as he witnessed the facts before entering its functions, he did not enjoy the immunity of the State agents and, therefore, can be included under the first hypothesis of 'individual acting in his private capacity'. ${ }^{219}$ In pursuance of the classical exception to the jurisdictional immunity, he was served a subpoena, as there was no link between his knowledge of the evidence and his present official functions.

On the other hand, if the agent works for the organisation, he is independent from his national States so that he does not possess the quality of State agent. In a case concerning an application for provisional release and involving the Special Representative of the Secretary-General for Kosovo, ${ }^{220}$ the Pre-Trial Judge refused to issue an order and to request the witness to testify on the accused's role in Kosovo. He seems to justify his decision by two elements: first, the witness is a UN agent and is leaving office; second, the order is therefore not indispensable. Yet, the Pre-Trial Judge invited the international agent to provide a mere statement on "his knowledge [...] of the risk that the accused would evade justice". ${ }^{221}$ It seems that, in this obscure decision, the PreTrial Judge tries to avoid the international agent's immunity. He might think it useless to issue a subpoena when the witness is leaving office. This vague caselaw is likely to puzzle a prospective applicant: may the Defence or the OTP be entitled to request the issue of a subpoena to international agents? If so, which are the requirements? Nonetheless, as the ICTY is empowered to issue subpoenas to peacekeepers owing to their international status, it should be enabled to issue subpoena ad testificandum and subpoena duces tecum to other international agents. At any rate, the Tribunal would have to obtain the permission and a waiver of the agent's immunity from the international organisation.

\footnotetext{
219 According to the Appeals Chamber, "State agents who, for instance, witnessed a crime before they took office, or found or were given evidentiary material of relevance for the prosecution or the defence prior to the initiation of their official duties [. . .] can legitimately be the addressees of a subpoena", 29 October 1997, Judgement on the Request of the Republic of Croatia for Review of the Decision of Trial Chamber II of 18 July 1997, Prosecutor/ Tihomir Bla·kić, IT-95-14-AR108bis, para. 49.

${ }^{220}$ Pre-Trial Judge, July 16th, 2003, Decision to Invite the Special Representative of the Secretary General to Submit a Statement, Prosecutor/Fatmir Limaj, Haradin Bala, Isak Muslin, IT-03-66-PT.

${ }^{221}$ Ibidem.
} 
Consequently, this power to issue subpoena to international agents qua individuals acting in their private capacity enables the Tribunal to impose penalties upon them in case of non-compliance of the order. Any international agent who refuses to produce the evidence or testify may be sentenced to contempt of tribunal under Rule 77 of the RPE. ${ }^{222}$ However, certain employees of international organisations may be exempted from complying with a subpoena.

\section{Section II. The limits to the ICTY power to subpoena international agents}

The Tribunal recognises certain privilege for the interpreters and war correspondents not to be compelled to testify ${ }^{223}$ and establishes specific proceedings including a balance of interests and the search for an alternative source of evidence. With regard to the employees of international organisations, the ICTY contemplates a protection for the agents of a humanitarian organisation (I) and an absolute immunity for the former employees of the Tribunal itself and for the ICRC personnel (II).

\section{The protection of the testimony of agents of a humanitarian organisation}

Although the privilege granted to interpreters and war correspondents is not extended to the personnel of humanitarian organisations, a certain balance of interests is contemplated.

In 2003, the representatives of a humanitarian organisation even recognised "an obligation at times to offer cooperation where that cooperation was sought, in the interests of justice". ${ }^{224}$ Hence, such an organisation and its employees should assist the ICTY for the production of evidence. Nevertheless, protective measures appear to be a precondition for the consent of the organisation to grant the witness permission to testify. The agents of a humanitarian entity do not enjoy a privilege against an order to testify, but they need to be protected. Indeed there is not only a risk that its mandate is compromised but also "security concerns for current and future personnel of the humanitarian organisation". ${ }^{225}$ Therefore, the Trial Chamber should exercise a balance between the

\footnotetext{
${ }^{222}$ For the details of the proceedings, see supra -Individuals-, Part I, Section II (I).

${ }^{223}$ Ibid.

${ }^{224}$ Transcript of February 25th, 2003, Prosecutor/Slobodan Milosevic, IT-02-54-T, at 16797-16798.

${ }^{225}$ Trial Chamber, April 1st, 2003, Decision on Prosecution Motion for Protective Measures (concerning a humanitarian organisation), Prosecutor/Slobodan Milosevic, IT-02-54-T.
} 
"interests sought to be protected and the accused's right to a fair and public hearing". ${ }^{226}$ In the Milosevic case, the Judges considered that a closed-session testimony would be an appropriate measure. In consequence, the employees of a humanitarian organisation are protected by the adjustment of the proceedings to the security concerns and the mission of the organisation ${ }^{227}$ and the ICTY keeps its powers for the production of evidence.

However, this decision creates a disparity between the agents of international humanitarian organisations: whereas some of them may be required to testify in a closed-session, others enjoy an absolute immunity.

\section{The absolute immunity of the employees of the ICTY and ICRC 228 from complying with a subpoena}

Both agents of the Tribunal and of the Committee enjoy a judicial or functional immunity that protects them from being compelled to testify.

The first judicial issue arises in the Celebici case wherein the Tribunal dealt with a motion from the defence requesting the issue of a subpoena to the former President and a Legal Officer of the ICTY. In its decision, the Appeals Chamber considered that the Tribunal agents "cannot be subpoenaed to testify as witnesses on matters relating to their official duties or functions because their work is integral to the operation of the Tribunal which must be protected by confidentiality". ${ }^{229}$ Even if ICTY employees enjoy an immunity, this is of a different kind: whereas the President is protected by a judicial immunity which is related to the independence of the administration of justice, the Legal Officer enjoys a "functional immunity in respect of the work which he per-

\footnotetext{
${ }^{226}$ Ibidem.

227 Whereas, when there is in question an individual enjoying a privilege (e.g. an interpreter or a war correspondent), the ICTY must strike a balance of the interests at stake and look for an alternative source of evidence.

${ }^{228}$ Two decisions contemplated this assumption: ICTY Trial Chamber, July 27th, 1999, Decision on the Prosecution motion under Rule 73 for the ruling concerning the testimony of a witness, Prosecutor/Blagoje Simić, Milan Simić, Miroslav Tadić, Stevan Todorović, Simo Zarić, IT-95-9-PT (This decision did not concern a subpoena since the witness was willing to appear; however, the solution of the Trial Chamber can be extended to the subpoenas all the more because the following decision concerning a subpoena upheld the solution); ICTY Trial Chamber, June 7th, 2000, Decision Denying Request for Assistance in Securing Documents and Witnesses from the International Committee of the Red Cross, Prosecutor/Blagoje Simić, Milan Simić, Miroslav Tadić, Stevan Todorović, Simo Zarić, IT-95-9-PT.

${ }^{229}$ ICTY Appeals Chamber, April 22nd, 1999, Decision on Motion to Preserve and Provide Evidence, Prosecutor/ Zejnil Delalić, Sdravko Mucic a/k/a 'Pavo', Hazim Delic, Esad Landzo a/k/a 'Zenga', IT-96-21-A.
} 
forms in relation to the Trial Chamber". ${ }^{230}$ In consequence, the ICTY is not empowered to subpoena its personnel, which enjoys immunities from giving evidence.

The second judicial issue concerns the agents of the ICRC. One may wonder whether "the ICRC has a relevant and genuine confidentiality interest such that the testimony of a former employee, who obtained the information while performing official duties, should not be admitted". ${ }^{231}$ The ICRC is a humanitarian independent institution. ${ }^{232}$ Created in 1863, it stems from a private initiative, but has acquired an international status since its mandate enables it to converse with States and belligerents in a dispute and given that it enjoys international legal personality. ${ }^{233}$ Its principles are neutrality, impartiality and independence. Yet, a forced testimony (subpoena ad testificandum or subpoena duces tecum) is likely to be prejudicial to the mission of the Committee. Its humanitarian actions during armed conflicts depend on a stable relationship with the host State. However, if the agents of the Committee were likely to testify or give evidence, especially of breaches of international humanitarian law, States would become reluctant to the intervention of the ICRC. Therefore, confidentiality must be preserved.

Nevertheless, two thesis may be upheld: either the relationship between the ICRC and the Tribunal is similar to the one between the Tribunal and States (whose national security concerns does not exonerate them from their duty to comply with a binding order ${ }^{234}$ ); or, this relation is comparable to the situation

${ }^{230}$ Separate Opinion of Judge David Hunt on Motion by Esad Landzo to Preserve and Provide Evidence, April 22nd, 1999, Prosecutor/ Zejnil Delalic, Sdravko Mucic a/k/a 'Pavo', Hazim Delic, Esad Landzo a/k/a 'Zenga', IT-96-21-A, para. 10.

${ }^{231}$ ICTY Trial Chamber, July 27th, 1999, Decision on the Prosecution motion under Rule 73 for the ruling concerning the testimony of a witness, Prosecutor/Blagoje Simić, Milan Simić, Miroslav Tadić, Stevan Todorović, Simo Zarić, IT-95-9-PT, para. 38.

${ }^{232}$ Article 1 of the Statutes of the ICRC as modified on June 24th, 1998.

${ }^{233}$ Swinarski (C.) (eds), Etudes et essais sur le droit international humanitaire et sur les principes de la Croix-Rouge en l'honneur de Jean Pictet, CICR-Nijhoff, Genève-La Haye, 1984, 1viii-1143. See especially the article of Prof. Reuter.

${ }^{234}$ The ICTY makes a balance of interests and adjusts the proceedings. First, the Trial Chamber may determine "whether, in view of a prima facie showing of a specified national security interest, a review of the relevant evidence is still required and, pursuant to such review, whether the specified national security interest of the State in non-disclosure of the relevant evidence outweighs the international public interest expressed by the SC in ensuring the effective administration of justice by the ICTY", Prosecutor's brief in support of subpoena duces tecum, Procureur/Tihomir Bla kić, $1^{\mathrm{er}}$ avril 1997, aff. IT-95-14-PT, p. 33. Second, in the Bla kić case, the Appeals Chamber suggested practical methods and procedures so as to reconcile "the authority of the International Tribunal to order and obtain from States all documents directly relevant to trial proceedings, and the legitimate demands of States concerning national security", 
of a lawyer who may systematically invoke his professional secrecy. According to the first assumption - upheld by the Prosecutor in the Simić case, the immunity of the ICRC could not be opposed to the ICTY so that the Committee cannot prevent its employees to appearing or producing evidence before it. The Tribunal could, proprio motu, be entitled to make a balance of interests, in order to decide whether the duty of confidentiality should prevail over the interests of justice. According to the second assumption, ${ }^{235}$ any form of testimony should be excluded for the employees of the ICRC because it would run counter to the lodestars of the Committee, especially its duty to preserve secrecy.

Eventually, the Trial Chamber considered that the obligation of confidentiality was the corollary of the principles of neutrality, independence and impartiality such that the agents of the ICRC may not appear before the tribunals. The Chamber even considered that this rule had acquired a customary value: "[t]he ratification of the Geneva Conventions by 188 States can be considered as reflecting the opinion juris of these State Parties, which, in addition to the general practice of States in relation to the ICRC as described above, leads the Trial Chamber to conclude that the ICRC has a right under customary international law to non-disclosure of the Information". ${ }^{236}$ This decision of the Tribunal, which grants the ICRC and its agents a complete immunity, had been challenged by Judge Hunt in his dissenting opinion appended to the Simić Judgement of 1999. He criticised the customary nature of the duty of non-disclosure: on the one hand, he underlines that the Trial Chamber only talked about a simple implied recognition by the States of this rule of confidentiality; on the other, he questions this State recognition. Therefore, the Judge suggests making a balance of interests at the end of which a determination could be made whether evidence held by the employees of the ICRC should be disclosed or not. Above all, he contemplates two hypotheses under which confidentiality should be removed: the evidence either clears the accused from the crime,

Appeals Chamber of the ICTY, 29 October 29th, 1997, Judgment on the Request of the Republic of Croatia for Review of the Decision of Trial Chamber II of 18 July 1997, Prosecutor/ Tihomir Bla·kić, IT-95-14-AR108bis, para. 67-68.

${ }^{235}$ This was the stance of the ICRC in the Simić case. The Committee, however, suggested a balance of interests when the Trial Chamber had jurisdiction to assess the confidentiality. This suggestion raised three elements likely to lead to the removal of the secrecy: "1) the crimes charged must be of the utmost gravity; 2) the evidence must be indispensable, in the sense that the case could not be mounted without it; and 3) admitting the evidence would not prejudice the work of the ICRC", ICTY Trial Chamber, July 27th, 1999, Decision on the Prosecution motion under Rule 73 for the ruling concerning the testimony of a witness, Prosecutor/Blagoje Simić, Milan Simić, Miroslav Tadić, Stevan Todorović, Simo Zarić, IT-95-9-PT, para. 19.

${ }^{236}$ Ibid., para. 74. 
or reinforces his culpability. ${ }^{237}$ Finally, his suggestion, reiterated in his separate opinion attached to the Simić Judgement of 2000, consists, in brief, of searching whether "the evidence to be given by the witness in breach of the obligations of confidentiality owed by the ICRC is so essential to the case of the relevant party as to outweigh the risk of serious consequences of the breach of confidence in the particular case". ${ }^{238}$ Although Judge Hunt's reasoning aimed at a fair trial, the removal of the immunity of the agents of the Committee is not relevant. Indeed, the duty of confidentiality is definitely one of the pillars of its humanitarian action; if the ICRC wants to carry on interfering in the conflicts to assist individuals, it must remain neutral and independent. However, how could it conciliate this requirement with a duty to testify before tribunals that have jurisdiction to prosecute those State officials who had allowed the ICRC to interfere into their territory? The interests of humanitarian action require that the obligation of non-disclosure prevail over the ICTY power to issue a subpoena. Moreover, the Trial Chamber upheld its decision in 2000 refusing to issue a subpoena to the Committee. ${ }^{239}$

Nevertheless, the ICRC and its employees enjoy a unique privilege that is even not granted to States, which cannot invoke their national security concerns so as to be exempted from complying with a binding order. This solution cannot be extended to all NGOs or international humanitarian entities which intervene in an armed conflict, but is specific to the ICRC, considering the nature of its mandate and its duties of confidentiality and neutrality. Therefore, the MSF, for instance, does not possess this immunity and no customary rule

${ }^{237}$ Judge Hunt identifies two situations where it may be necessary that the international criminal Judges "should have the final say. The first situation is where the evidence of an official or employee of the ICRC is vital to establish the innocence of the accused person. [. . .] The second situation [. . . ] is where the evidence of an official or employee of the ICRC is vital to establish the guilt of the particular accused in a trial of transcendental importance", Separate Opinion of Judge David Hunt on Prosecutor's Motion for a Ruling Concerning the Testimony of a Witness, ICTY Trial Chamber, July 27th, 1999, Prosecutor/Blagoje Simić, Milan Simić, Miroslav Tadić, Stevan Todorović, Simo Zarić, IT-95-9-PT, para. 28-33.

${ }^{238}$ Separate Opinion of Judge David Hunt on Motion by Todorović for Order Requesting Assistance of the International Committee of the Red Cross, ICTY Trial Chamber, June 7th, 2000, Prosecutor/Blagoje Simić, Milan Simić, Miroslav Tadić, Stevan Todorović, Simo Zarić, IT-95-9-PT, para. 6; Separate Opinion of Judge David Hunt on Prosecutor's Motion for a Ruling Concerning the Testimony of a Witness, ICTY Trial Chamber, July 27th, 1999, Prosecutor/ Blagoje Simić, Milan Simić, Miroslav Tadić, Stevan Todorović, Simo Zarić, IT-959-PT, para. 35.

${ }^{239}$ ICTY Trial Chamber, June 7th, 2000, Decision Denying Request for Assistance in Securing Documents and Witnesses from the International Committee of the Red Cross, Prosecutor/Blagoje Simić, Milan Simić, Miroslav Tadić, Stevan Todorović, Simo Zarić, IT-959-PT. 
of confidentiality protects its agents who might be subpoenaed. However, as doctors, they may invoke their professional secrecy, but "it is remarkable that MSF, or its French section at least, seems to envisage fewer problems in cooperating with the Tribunal than does the ICRC" ${ }^{240}$ Médecins Sans Frontière succeeds in establishing a certain balance "in reconciling operational neutrality with human rights objectivity". ${ }^{241}$ Indeed, MSF agrees to cooperate with the Tribunal and to provide it with documents and testimonies on a confidential basis. Such information not subject to disclosure is regulated by Rule 70 of the RPE. ${ }^{242}$

Eventually, this study of the ICTY power to request international entities and their agents to produce evidence reveals two opposite movements: whereas the power to issue binding orders to international organisations has been gradually extended, the jurisdiction to subpoena international agents is narrowed. On the one hand, on the grounds of the organic link between the Tribunal and the Security Council, the Judges first recognised their power vis-à-vis UN entities, and, in particular, peacekeeping operations. Then, they extended it towards other intergovernmental organisations such as the EUMM. On the other hand, given the extensive interpretation of the term "individuals acting in their private capacity", the ICTY established its power to subpoena peacekeepers. And, remaining vague on its authority over others international agents, it modified

${ }^{240}$ Hampson (F. J.), supra [note 122], at 68. See also Faite (A.), Crimes in Times of Armed Conflicts : the Problem of Testimony in Court of Humanitarian Organisations, LL.M. Dissertation, University of Essex, unpublished, quoted in Hampson (F. J.), ibid., note 34.

${ }^{241}$ Hampson (F. J.), supra [note 122], p. 69.

${ }^{242}$ This Rule provides, inter alia, that: “(B) If the Prosecutor is in possession of information which has been provided to the Prosecutor on a confidential basis and which has been used solely for the purpose of generating new evidence, that initial information and its origin shall not be disclosed by the Prosecutor without the consent of the person or entity providing the initial information and shall in any event not be given in evidence without prior disclosure to the accused. (C) If, after obtaining the consent of the person or entity providing information under this Rule, the Prosecutor elects to present as evidence any testimony, document or other material so provided, the Trial Chamber, notwithstanding Rule 98, may not order either party to produce additional evidence received from the person or entity providing the initial information, nor may the Trial Chamber for the purpose of obtaining such additional evidence itself summon that person or a representative of that entity as a witness or order their attendance. A Trial Chamber may not use its power to order the attendance of witnesses or to require production of documents in order to compel the production of such additional evidence. (D) If the Prosecutor calls a witness to introduce in evidence any information provided under this Rule, the Trial Chamber may not compel that witness to answer any question relating to the information or its origin, if the witness declines to answer on grounds of confidentiality". Ergo, under Rule 70 of the RPE, agents of an international organisation may voluntarily supply evidence to the Tribunal on a confidential basis, but are protected from being compelled to testify or to produce it. 
the proceedings to protect the agents of a humanitarian organisation and restricted its power vis-à-vis its own agents or the employees of the ICRC (due to the specificity of the mission of both the Tribunal and the Committee). The ICTY case-law leads to an iniquity between the agents of international entities so that an effort of rationalisation should be made.

One may wonder whether this reasoning will apply before the new ICC. It is worth pointing out that both concepts of binding orders and subpoenas do not appear within the Rome Statute or the Rules of the Court. Nonetheless, firstly, the duty to cooperate for the organisation is included in the Statute; ${ }^{243}$ and secondly, the absolute immunity of the ICRC personnel is destined to disappear in pursuance of Rule $73 .{ }^{244}$ Therefore, it seems that even if the ICC is not vested with any enforcement power, not only the role of the international entities and agents for the production of evidence is considered in the Statute and Rules, but also the proper administration of justice appears to prevail over the specific protective status of certain international entities. This may be the first step towards the rationalisation of the proceedings.

\footnotetext{
${ }^{243}$ Article 87 (6) of the Rome Statute. However, the production of evidence will be subject to the conclusion of an agreement with the organisation, agreed that such an agreement has to be in accordance with the organisation's competence or mandate. See also Article 54 (3) (c) which states that the Prosecutor may seek the assistance of any "intergovernmental organization or arrangement in accordance with its respective competence and/or mandate". In addition, as Annalisa Ciampi points out, "the Statute does not rule out the possibility that an international organisation has a duty to provide information to the Court when requested to do so, e.g. on the basis of a resolution of the Security Council acting under Chapter VII of the UN Charter", Ciampi (A.), «The Obligation to Cooperate », in Cassese (A.), Gaeta (P.) and Jones (J.R.W.D.), The Rome Statute of the International Criminal Court: A Commentary, Oxford University Press, 2002, vol. II, at 1620 .

${ }^{244}$ Rule 73 seems to accept Judge Hunt's position: “4. The Court shall regard as privileged, and consequently not subject to disclosure, including by way of testimony of any present or past official or employee of the International Committee of the Red Cross (ICRC), any information, documents or other evidence which it came into the possession of in the course, or as a consequence, of the performance by ICRC of its functions under the Statutes of the International Red Cross and Red Crescent Movement, unless: (a) After consultations undertaken pursuant to subrule 6, ICRC does not object in writing to such disclosure, or otherwise has waived this privilege; or (b) Such information, documents or other evidence is contained in public statements and documents of ICRC. [ . . .] 6. If the Court determines that ICRC information, documents or other evidence are of great importance for a particular case, consultations shall be held between the Court and ICRC in order to seek to resolve the matter by cooperative means, bearing in mind the circumstances of the case, the relevance of the evidence sought, whether the evidence could be obtained from a source other than ICRC, the interests of justice and of victims, and the performance of the Court's and ICRC's functions".
} 